\title{
Jurassic - Cretaceous boundary strata of the extreme Arctic (Peary Land, North Greenland)
}

\author{
ECKART HÅKANSSON, TOVE BIRKELUND, STEFAN PIASECKI and VICTOR ZAKHAROV
}

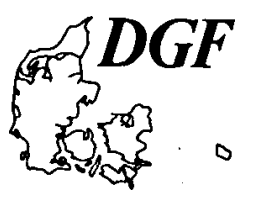
Håkansson, E., Birkelund, T., Piasecki, S. and Zakharov, V.: Jurassic - Cretaceous boundary strata of
the extreme Artic (Peary Land, North Greenland). Bull. geol. Soc. Denmark, vol. 30, pp. 11-42.
Copenhagen, November 12th, 1981. https://doi.org/10.37570/bgsd-1981-30-02

\begin{abstract}
A fossiliferous Late Jurassic-Early Cretaceous sequence is described from the Wandel Sea Basin, eastern North Greenland. The area was transgressed in the Middle Oxfordian and a gradually shallowing marine regime prevailed until Early Valanginian time, when conditions became limnic. Stratigraphic data based on dinoflagellate cysts, ammonites and Buchia species indicate the presence of strata of Middle and Late Oxfordian, Kimmeridgian, Middle and Late Volgian, Early and Late Ryazanian, and Early Valanginian ages. Both the dinoflagellate assemblages and the mollusc faunas show close similarity to assemblages from the Sverdrup Basin of the Canadian Arctic Archipelago, Svalbard and northern USSR. They are also linked to more southern Boreal and Sub-Boreal areas in East Greenland, England, the Russian Platform and to some extent, North America. An integrated dinoflagellate-ammonite-Buchia stratigraphy shows that the Early Cretaceous dinoflagellate assemblage appeared later in the Wandel Sea Basin than further south. It is also seen that a discrete "Jurassic" dinoflagellate assemblage existed for some time in the Early Cretaceous unaffected by the general turn-over at the Jurassic-Cretaceous boundary. Dinoflagellate, ammonite and Buchia assemblages are briefly discussed and selected species figured.
\end{abstract}

E. Håkansson and T. Birkelund, Institute of Historical Geology and Palaeontology, Oster Voldgade 10, 1350 Copenhagen K, Denmark. S. Piasecki, Geological Survey of Greenland, Dster Voldgade 10, 1350 Copenhagen K, Denmark. V. A. Zakharov, Institute of Geology and Geophysics, Siberian Academy of Sciences of the USSR, Universitetskiy Prospekt 3, 630090 Novosikirsk 90, USSR. February 18th, 1981.

In 1978 the first systematic mapping campaign into North Greenland was initiated by the Geological Survey of Greenland (GGU). During the first season of this campaign a hitherto unknown sequence of sediments spanning the Jurassic - Cretaceous boundary was revealed in the Wandel Sea Basin (Håkansson 1979). The presence of a number of faunas comprising both ammonites and Buchia as well as a content of dinoflagellate cysts at many levels indicate the location of the boundary within a sequence which, in general, records a transition from shallow marine to limnic, clastic environments.

\section{Regional geology}

The Wandel Sea Basin was an area of deposition from the Late Palaeozoic to the Palaeogene (Dawes \& Soper 1973). Thus, its age is comparable to a number of other sedimentary basins, fringing the present Arctic Ocean. Harland (e.g. 1965, 1969) and Christie (1979), among others, have discussed the parallel development of the Sverdrup Basin and Svalbard, and have stressed the location of these as close to the Wandel Sea Basin in a pre-drift configuration of the continents.

Mapping of the Wandel Sea Basin sediments throughout their known distribution from Lockwood $\varnothing$ in the north to Holm Land in the south (Håkansson 1979; Håkansson, Heinberg \& Stemmerik in press) has accentuated the similarity to these basins through large parts of the sequence. However, the particular interval of time described in the present paper is not too well known in Svalbard and the Sverdrup Basin, rendering a detailed comparison difficult.

The mapping of the Wandel Sea Basin has revealed an unexpected mosaic distribution of rocks of Mesozoic and younger ages. To a large extent this pattern is controlled by a system of prominent NW-SE trending faults that dissect most of the basin (fig. 1). Although these faults have been active several times during the history of the basin (Håkansson 1979; Håkansson \& Pedersen 1981), direct influence of the move- 


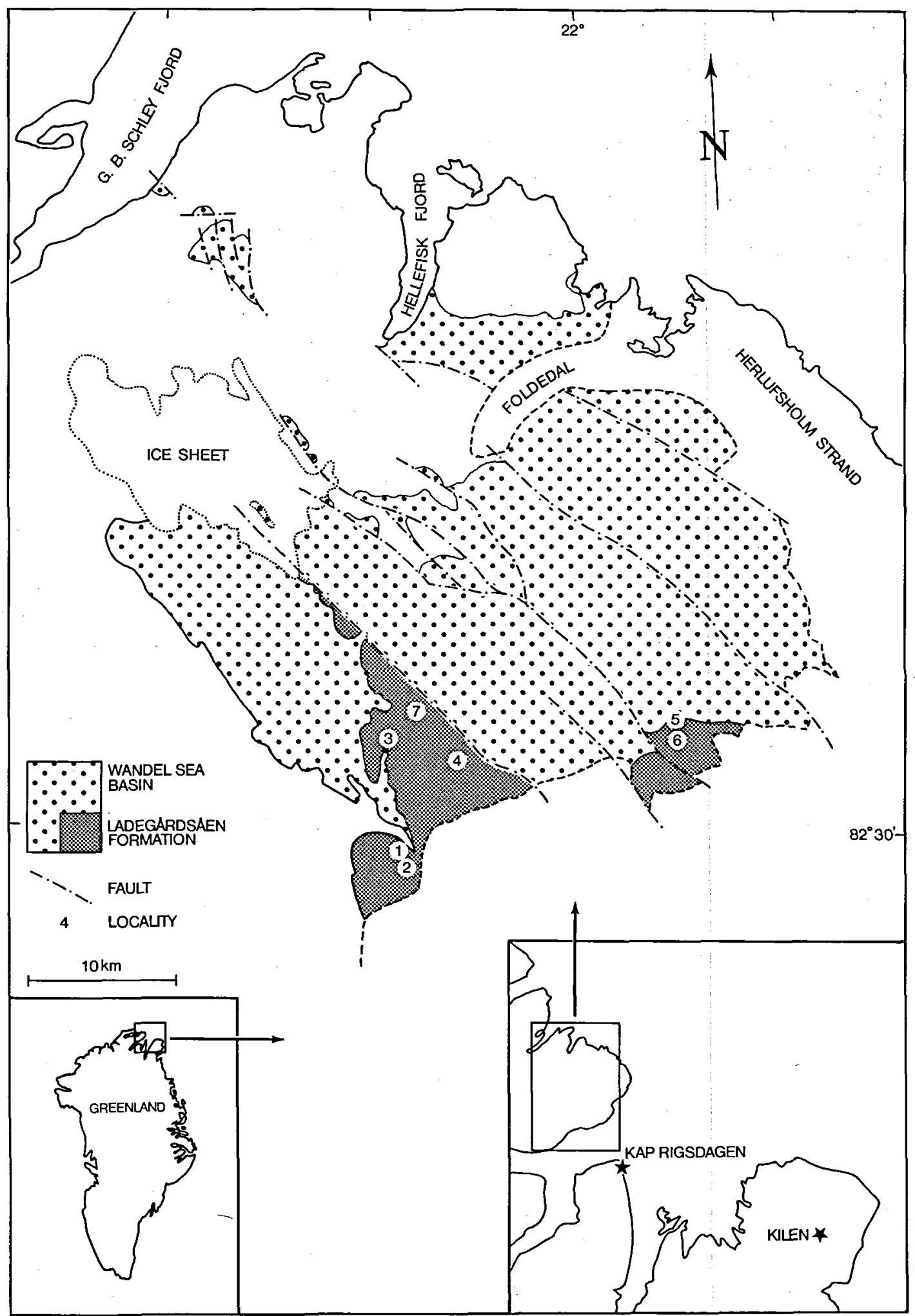

Fig. 1. Geological sketch map of the Kim Fjelde area, eastern Peary Land (simplified from Hăkansson 1979). Locality 1-6 indicate the sites of the sections illustrated in fig. 2; locality 7 indicates the site of GGU 196316; GGU 196317 \& 196350-352 were collected between loc. 4 and 7 . Additional Late Jurassic and Early Cretaceous occurrences in the Wandel Sea Basin are indicated on the inserted map (cf. Håkansson et al. in press). 
ments on the sedimentation can only occasionally be demonstrated in the sequence preserved.

In accordance with the mosaic distribution pattern sediments of Early Cretaceous age have been located in three distinct areas within the Wandel Sea Basin (fig. 1). In Kilen, Kronprins Christian Land (Håkansson et al. in press) and in Kim Fjelde, eastern Peary Land, have sediments been preserved that represent the Jurassic-Cretaceous transition.

Håkansson (1979) referred the Jurassic-Lower Cretaceous deposits of Kim Fjelde to the new Ladegårdsåen Formation, which is described in some detail below.

\section{Ladegårdsåen Formation}

Name: The formation was named after the stream Ladegårdsåen which drains the area where Jurassic sediments were first discovered in Peary Land (Håkansson 1979).

Distribution: The Ladegårdsåen Formation crops out in a number of fault blocks along the southern rim of Kim Fjelde, eastern Peary Land, and is not known outside this region. The westernmost fault block constitutes the type area.

Boundaries: The formation rests with an erosional contact on a bedrock mosaic of Silurian, Carboniferous, and Permian sediments. The upper boundary is not preserved, and only Quaternary deposits have been found overlying the sequence.

Thickness: The formation is some $175 \mathrm{~m}$ thick in the type area, but increases to the east, where a greater thickness of the younger part is preserved. Owing to the character of the exposures in that area, however, estimates of the maximum thickness are uncertain.

Lithology and fossil content: The formation is dominated by soft shaly to virtually unconsolidated fine-grained sands containing a number of more or less prominent coarse-grained intervals. In general, exposures are very poor. The lithological development in the two main areas appears to be somewhat different, partially as a result of variations in the local diagenetic history. However, on the basis of the most promi- nent coarse sandstone, a lithological correlation has been suggested previously (Håkansson 1979). Following this correlation, the Ladegårdsån Formation may be divided into a number of informal units (fig. 2).

Basal conglomerate (unit a): The basal beds of the formation have been found at only two localities, both within the western fault block. Here, broad, shallow depressions in the eroded bed-rock surface have been filled with pebbly, biogenic conglomerates. Typically, these depressions are less than $25 \mathrm{~cm}$ deep, but additional thin conglomerate beds of similar composition may be found up to $10 \mathrm{~m}$ above the boundary.

The most conspicuous type of clasts are belemnites and belemnite fragments but, in addition, a large number of pelecypod shells have accumulated. In general the preservation appears to be good so that, in spite of the lack of bivalved specimens, there is little doubt that this diverse fossil assemblage has been subjected only to very mild transport. Among the clasts of the conglomerate are subordinate amounts of locally derived bedrock pebbles, including both Silurian shale and sandstone, and Late Carboniferous chert and bryozoans.

The matrix of the conglomerate is very finegrained quartz sand, which is usually well cemented with calcite.

Lower shaly and sandy unit (units $b$ and c): This part is composed predominantly of very fine- to fine-grained sand similar to the conglomerate matrix below; in the upper half of the unit are thin beds of coarser, poorly sorted sand.

The lower unit (unit b) of the western fault block is composed of soft, crumbly shales containing spheroidal, loosely cemented concretions reaching one meter in diameter. At certain levels huge, partly coalesced doggers occur, well cemented by calcite. In the western fault block no faunal elements have been found in these strata, but a well-preserved dinoflagellate flora is present.

In the eastern fault block the lowermost levels consist of slightly coarser sands, which have been more uniformly cemented, and - judging from the colour - contain significant amounts of ferruginous material. Almost all primary structures have been obliterated through the cementation 

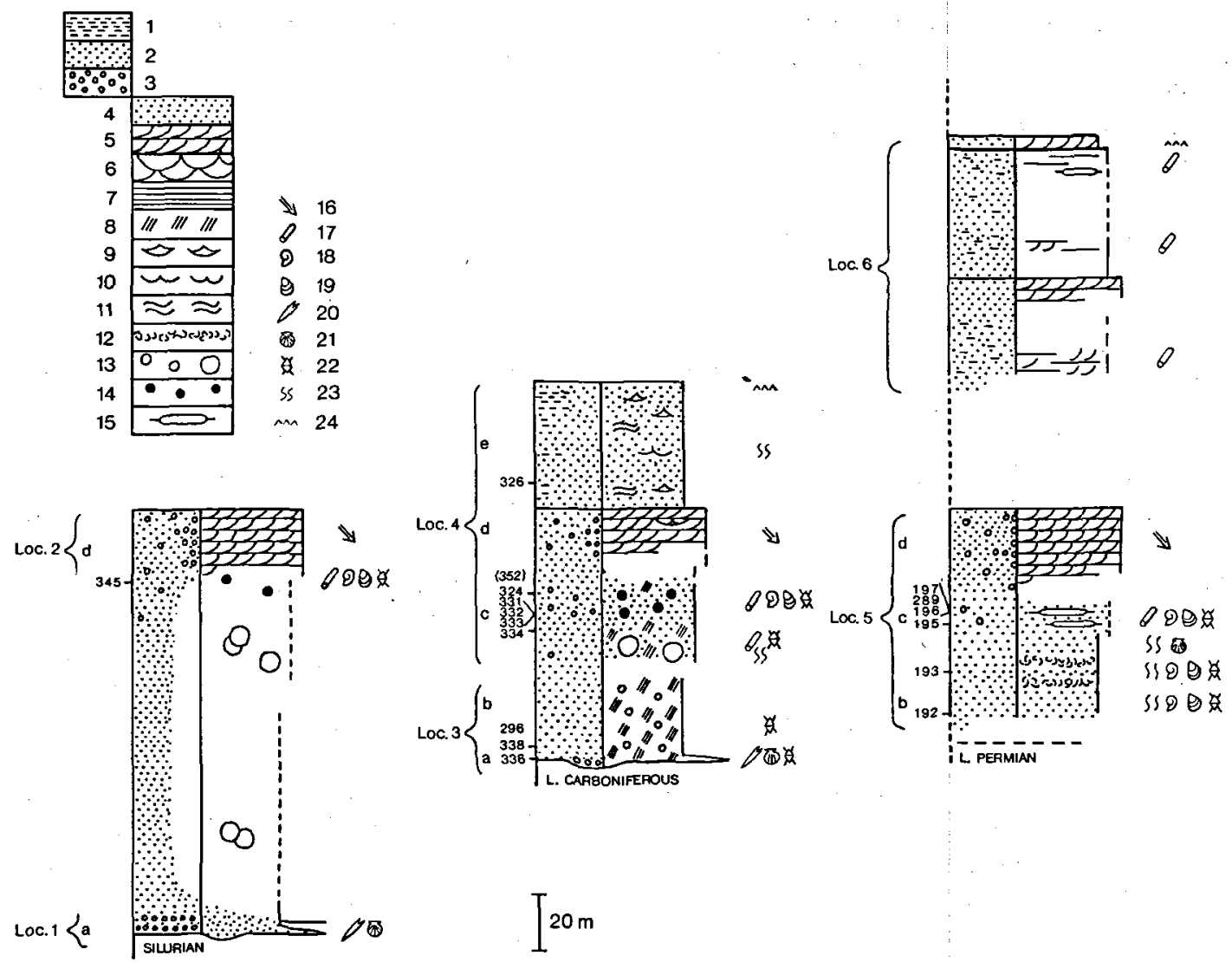

Fig. 2. Ladegårdsåen Formation. Composite sediment logs of the main fault blocks arranged with the prominent top level of unit $\mathrm{d}$ as datum-line. Sediment: 1 mud, 2 sand, 3 gravel; structures: 4 structureless, 5 planar cross beds, 6 trough cross beds, 7 horizontal lamination, 8 cross lamination, 9 lenticular lamination, 10 flaser lamination, 11 wavy lamination, 12 shell bed, 13 calcitic concretions, 14 phosphoritic concretions, 15 sideritic concretions; additional information: 16 direction of transport, 17 wood, 18 ammonites, 19 Buchia, 20 belemnites, 21 other pelecypods, 22 dinoflagellates, 23 bioturbation, 24 root horizon. Sample information (left of log): sample level; GGU sample number (first three ciphers omitted); informal lithological unit (a - e, see the text); locality number (cf. fig. 1).

processes. These beds yield a fairly diverse fauna comprising well preserved, only slightly transported pelecypods and worm tubes in addition to ammonites.

Somewhat higher in the sequence (unit c) poorly exposed, fine-grained sands seem to dominate, although the abundant concretions apparently have been developed preferentially in poorly sorted sand which may even contain some gravel. In the eastern fault block the concretions are predominantly sideritic, whereas in the western fault block they are phosphoritic. Most concretions are packed with remarkably uniform assemblages of ammonites, commonly fragmented, together with bivalved Buchia specimens of all sizes as well as abundant wood fragments. The remaining fauna is limited to a few gastropods and decapod crustacean carapaces. Outside the concretions in the finegrained sands, only wood fragments and scattered tree-trunks have been seen in addition to indistinct vertical burrow structures.

Middle prominent sandstone (unit d): This unit consist of up to $30 \mathrm{~m}$ of fine- to coarse-grained quartz sand which is, in general, sufficiently cemented to form a distinct topographic feature; commonly it is further characterized by bright reddish and brownish colours particularly in the lower part. The sandstone is typically developed as giant scale, planar cross beds with individual sets commonly exceeding $2.5 \mathrm{~m}$. Some grading is 
often visible within the single foreset beds. The direction of transport is generally towards the southeast, and no regional variation has been noted. Neither trace fossils nor body fossils have been recorded from this unit.

Upper sands and sandstones: This part of the formation is dominated by unconsolidated finegrained sand and therefore always poorly exposed.

In the western fault block the sequence (unit e) is a fine-grained sand commonly developed as a heterolith with mud partings and layers dominated by carbonaceous, organic debris. Apart from a dinoflagellate assemblage found not far above unit $d$, only a few root horizons and indistinct burrow structures were recorded in this unit. Nowhere in the western fault block have more than $50 \mathrm{~m}$ above unit $\mathrm{d}$ been left by Quaternary erosion.

In the eastern outcrops, on the other hand, the thickness preserved above unit $d$ may be well in excess of $150 \mathrm{~m}$, although overestimates due to structural duplications cannot be excluded. Sediments corresponding to unit e have not been found exposed in these fault blocks, but at somewhat higher stratigraphic levels a sequence has been investigated which seems to be representative of most of the sediments exposed in the eastern fault block. It is predominantly composed of sand containing varying amounts of comminuted carbonaceous debris and, more rarely, notable amounts of kaolinized mineral grains. Finegrained sand dominates, but there are a few coarse-grained beds. Wood fragments or even logs are present at most levels and these are commonly strongly impregnated with siderite. Apart from the very poorly preserved wood, coalified roots and plant remains constitute the only macrofossils noted.

Depositional environments: The transgression indicated by the basal conglomerate with its diverse fossil assemblage (unit a) was followed by marine shallow water sediments deposited in fairly tranquil environments, as judged from the fauna (unit b). Higher parts of the sequence show a trend towards deposition in a marine regime characterized by higher energy levels (parts of unit c), culminating in the barren crossbedded sandstone (unit d), which is thought to be a near-shore deposit from a period with a high sediment influx.

In spite of the poor exposures it is evident that the upper sands and sandstones (e.g. unit e) are of non-marine origin, but, as evidenced by the dinoflageliate assemblage, with occasional marine incursions in the basal part.

\section{Age of the Ladegårdsåen Formation}

The age of the formation has been determined by means of ammonites, Buchia and dinoflagellate cysts.

A large number of samples were investigated for their possible content of dinoflagellate cysts, but only 14 samples actually contained any. Fortunately, these assemblages supplement to a large extent the stratigraphic data based on macrofossils. It should be noted, however, that no fossil data have so far been accumulated to reveal the age of the upper part of the formation.

Oxfordian ammonite zones referred to below are those of the Boreal - Sub-Boreal zonation defined by Sykes \& Callomon (1979) on the basis of sequences in Scotland and East Greenland (see also Callomon \& Birkelund 1980). The Middle Volgian - Early Valanginian zonation used in the present paper follows that of Birkelund, Callomon \& Fürsich (1978). This part of the zonation is mainly defined on the basis of northern Siberian occurrences (e.g. Saks and Shulgina in Saks 1972; Zacharov \& Mesezhnikov 1974), but is also applicable in East Greenland and, to some extent, in England.

\section{Middle Oxfordian - Early Volgian}

Three samples from the lowermost part of the formation (loc. 3 , fig. 1) have yielded a sequence of well preserved dinoflagellate assemblages of low diversity, but including a number of well established zonal species (fig. 3).

The lowermost sample (GGU 196336) from the basal conglomerate contains almost no palynomorphs, but Gonyaulacysta scarburghensis has been identified. In NW Europe and in East Greenland this species has its latest occurrence in the Cardioceras densiplicatum Zone of the Middle Oxfordian (Sarjeant 1979; Piasecki 1980) as may also be the case in Svalbard (Bjærke in press) and the Sverdrup Basin (Johnson \& Hills 


\begin{tabular}{|c|c|c|c|c|c|c|c|}
\hline \multicolumn{3}{|c|}{ S PECIES } & 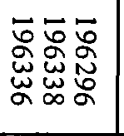 & 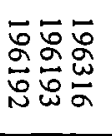 & 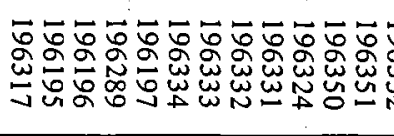 & 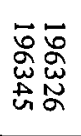 & 点 \\
\hline \multicolumn{3}{|c|}{$\begin{array}{l}\text { Gonyaulacysta scarburghensis } \\
\text { Gonyaulacysta jurassica } \\
\text { Ambonosphaera sp. } \\
\text { Lanterna sarturnalis } \\
\text { Gonyaulacysta jurassica ssp. longicornis } \\
\text { Paragonyaulacysta borealis } \\
\text { Leptodinium aff. hyalodermopsis } \\
\text { Sentusidinium myriatrichum } \\
\text { Gonyaulacysta sp. } \\
\text { Tanyosphaeridium isocalamus } \\
\text { Gonyaulacysta helicoidea } \\
\text { Cleistosphaeridium sp. } \\
\text { Oligosphaeridium complex } \\
\text { Muderongia tetracantha }\end{array}$} & $\begin{array}{r}\bullet: \\
\bullet \\
\bullet \\
: \\
: \\
:\end{array}$ & $\begin{array}{l}\bullet \bullet \\
\bullet \bullet \\
0 \\
\bullet \bullet \\
\bullet \bullet\end{array}$ & $\begin{array}{lll}\bullet & \bullet \bullet & \bullet \\
\bullet & \bullet & \bullet \\
& \bullet & \bullet\end{array}$ & $\because$ & 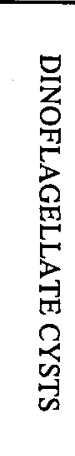 \\
\hline \multicolumn{3}{|c|}{$\begin{array}{l}\text { Buchia russiensis } \\
\text { Buchia fischeriana } \\
\text { Buchia unschensis } \\
\text { Buchia terebratuloides } \\
\text { Buchia okensis } \\
\text { Buchia volgensis } \\
\text { Buchia keyserlingi }\end{array}$} & & •. & 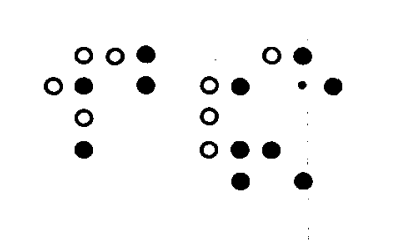 & $v$ & $\stackrel{\text { 号 }}{\stackrel{\Xi}{\Xi}}$ \\
\hline \multicolumn{3}{|c|}{$\begin{array}{l}\text { Dorsoplanites gracilis } \\
\text { Craspedites okensis } \\
\text { Borealites sp. aff. fedorovi } \\
\text { Peregrinoceras sp. aff. albidum } \\
\text { Neotsllia sp. }\end{array}$} & & $\bullet 0$ & 0 & $\bullet$ & 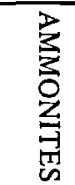 \\
\hline \multirow{3}{*}{ 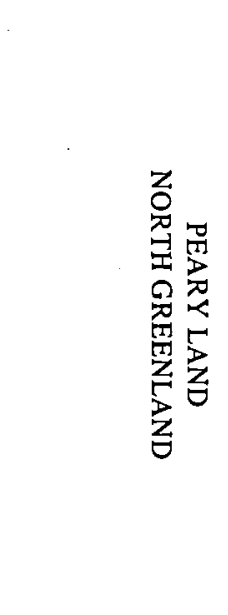 } & \multirow{3}{*}{ 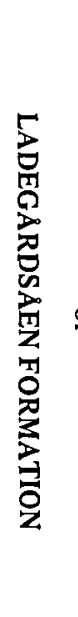 } & \multirow{3}{*}{ 。号 } & & 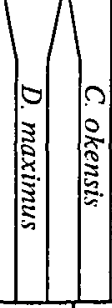 & $\begin{array}{l}1 \\
\vdots \\
0 \\
\vdots \\
\vdots \\
\vdots\end{array}$ & & 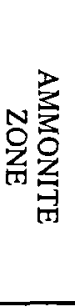 \\
\hline & & & 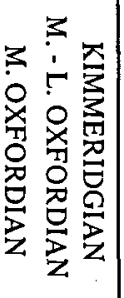 & $\begin{array}{l}3 \mid r \\
\vdots \\
\vdots \\
\vdots \\
2 \\
2\end{array}$ & RYAZANIAN & 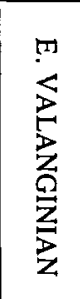 & 第 \\
\hline & & & J U R A & S S I C & C RETA CEOUS & & 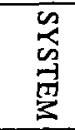 \\
\hline
\end{tabular}

Fig. 3. Stratigraphic distribution of selected taxa in the Ladegårdsåen Formation (sample sites indicated in fig. 1). Only the ammonite zones actually demonstrated have been included (for a full zonal scheme see Birkelund et al. 1978a). 
1973). Since G. scarburghensis is not present higher in the sequence in Peary Land, the age of this sample is regarded as Middle Oxfordian, possibly equivalent to the $C$. densiplicatum Zone.

Five metres above the basal conglomerate (GGU 196338) an assemblage containing Paragonyaulacysta borealis and Ambonosphaera sp. have been recovered. The former species occurs for the first time in the Late Oxfordian of East Greenland (Piasecki 1980) and appears in the middle of the Oxfordian in northern Canada (Brideaux \& McIntyre pers. comm.). Ambonosphaera sp. is restricted to the time interval from the Amoeboceras glosense Zone to the Amoeboceras rosenkrantzi Zone in the Late Oxfordian of East Greenland (Piasecki 1980). The age of the sample therefore is assumed to be Late Oxfordian, and most likely no younger than the Amoeboceras regulare Zone, since several of the species in the next higher sample from Peary Land occur for the first time in the $A$. rosenkrantzi Zone in East Greenland (Piasecki 1980).

In the third sample (GGU 196296) the presence of Lanterna saturnalis and Leptodinium aff. hyalodermopsis indicate a Late Oxfordian Kimmerigian age as these species occur for the first time in the $A$. rosenkrantzi Zone in East Greenland (Piasecki 1980). As mentioned above, Ambonosphaera sp. was present in the sample below and, as this species in East Greenland has been found up to the Oxfordian - Kimmeridgian boundary, the sample is assumed to be of earliest Kimmeridgian age.

Thus, the basal sample in this sequence dates the transgression at locality 3 (fig. 1) to the Middle Oxfordian (?C. densiplicatum Zone), but within only some metres of shaly sand above the age is already Kimmeridgian. Unfortunately no microfossils are preserved in the highly similar basal conglomerate at locality 1 (fig. 1). However, in spite of the greater accumulation of sediment (fig. 2) it is not considered likely that the transgression here was significantly earlier. No other age-diagnostic fossils have been identified from this lower part of the formation.

Previous indications of the presence of Middle Jurassic strata in the Wandel Sea Basin (Dawes 1976) have not been directly verified during the recent extensive mapping programme (Håkansson et al. in press). From Kilen (fig. 1) scattered faunas dating from the Kimmeridgian to the Valanginian have been provisionally identified. However, due to the structural complexity of Kilen (cf. Håkansson et al. in press) the presence of still older strata may not be excluded. The youngest age-diagnostic fossils so far found to predate the transgression of the Ladegårdsån Formation indicate an Anisian (Middle Trias age (Håkansson \& Heinberg 1977). The major Jurassic transgression in the Wandel Sea Basin, therefore, is in good agreement with the mid Oxfordian, marine maximum discussed by Hallam (1978).

\section{Middle - Late Volgian}

The age of this part of the formation is dated mainly by occurrence of ammonite and Buchia species and only to a very small extent on the basis of dinoflagellate cysts, of which those present are mostly long-ranging species.

The lower group of samples are of Middle Volgian age. Two of these (GGU 196192, 196193) contain Dorsoplanites gracilis, a species recorded by Spath (1936) from the base of the Glauconitic Series (or even below) to the top of the Glauconitic Series and sandy shales above ( $\alpha$ concretions) in Milne Land, East Greenland.

New stratigraphic work from Milne Land (Callomon \& Birkelund unpublished) shows that $D$. gracilis s.l. occurs in a number of successive faunas, which may be correlated in part with the Dorsoplanites ilovaiskii and Dorsoplanites maximus Zones of the Middle Volgian of the Subarctic Urals (see Zakharov \& Mesezhnikov 1974). The most closely related specimens are found within the upper part of the range of the species in the faunas from Krebsedal ('Crab Valley') described by Spath, and Siberian occurrences described by Mikhailov (1966) are from the $D$. maximus Zone.

From the lower group of samples in Peary Land a few Buchia specimens were also collected; $B$. russiensis in sample GGU 196192 and B. fischeriana in GGU 196193. Only B. russiensis is restricted to the Middle? Volgian, while $B$. fischeriana is widespread from the Middle Volgian to the early Ryazanian.

A single sample (GGU 196316, fig. 1) contains a number of not too well preserved ammonite fragments and Buchia specimens. The ammonite 
fragments are close to Craspedites okensis and indicate a Late Volgian age. In northern Siberia the Late Volgian is divided into 3 zones: Craspedites okensis Zone, Craspedites (Taimyroceras) taimyrensis Zone, and Chetaites chetae Zone. The sample is tentatively referred to the $C$. okensis Zone because the ammonite fragments seem to be closer to Craspedites s. str. than to the later subgenus Taimyroceras that characterizes the $C$. taimyrensis Zone. The Buchia specimens belong to the $B$. fischeriana, $B$. unschensis and $B$. terebratuloides complexes, which is in accordance with a Late Volgian age.

\section{Ryazanian}

The dinoflagellate floras are also dominated by long ranging species in this part of the sequence (see fig. 3).

The Ryazanian samples contain rich Buchia assemblages, characterized by $B$. fischeriana, $B$. unschensis, B. terebratuloides, B. okensis and $B$. volgensis. $B$. fischeriana, $B$. unschensis and $B$. terebratuloides appear $\mathrm{i}$ the Volgian, while both $B$. okensis and $B$. volgensis are thought to appear at the base of the Hectoroceras kochi Zone. All species became extinct in the Ryazanian, and only two are present with certainty above the $H$. kochi Zone. B. volgensis is most common in the Surites analogus Zone and rare occurrences of $B$. okensis are similarly known from that zone.

The Ryazanian Buchia assemblages from a substantial number of samples (fig. 3) are thus diagnostic of the $H$. kochi Zone. Furthermore, at least two samples from these levels (GGU 196332, 196333) contain specimens of Borealites sp. aff. fedorovi. The ammonite genus Borealites appears in the Chetaites sibiricus Zone of northern Siberia and becomes more diversified in the lower part of the H. kochi Zone (Casey 1973). The specimens from Peary Land are closest to forms from northern and western Siberia, all from the $H$. kochi Zone (Shulgina and Klimova in Saks 1972)

In the higher parts of the Ryazanian sequence of the western fault block, two samples (GGU 196351, 196352) contain Peregrinoceras sp. aff. albidum. The genus Peregrinoceras appears late in the Ryazanian and is not known from the Valanginian. $P$. albidum characterizes a zone at the top of the Upper Ryazanian in Eastern England (Casey 1973), and P. aff. albidum Casey, 1973 has now also been found at Kashpur $20 \mathrm{~cm}$ below the Valanginian (Casey, Mesezhnikov \& Shulgina 1977). The Peary Land occurrences may indicate the presence of the Bojarkia mesezhnikowi Zone of the northern Siberian zonation.

A third sample (GGU 196350) from approximately the same level as $P$. sp. aff. albidum has yielded a single specimen of $B$. unschensis, which may indicate an age slightly earlier in the Ryazanian than the Late Ryazanian ammonites.

\section{Valanginian}

The topmost sample yielding marine macrofossils was found immediately below unit d (GGU 196345). It contains poorly preserved fragments of Neotollia as well as a single Buchia shell, which is probably a young specimen of $B$. keyserlingi. It seems most probable, therefore, that this sample has an Early Valanginian age.

All dinoflagellate cysts found at this level are either previously undescribed or long ranging forms which dominate also in the VolgianRyazanian sequence below (fig. 3). However, a few metres above unit $d$ has been found a flora of unquestionable Valanginian age. The sample (GGU 196326) has a low content of cysts, and only a single species, Oligosphaeridium complex, is well represented. However, the spectrum of species in general is markedly different from that in the older samples, and $O$. complex together with Muderongia tetracantha is generally reported to occur for the first time in the Lower Valanginian (Thusu in Birkelund et al. 1978b).

This sample provides the only age determination so far available from the extensive sequences above the prominent unit $d$.

\section{Topmost undated part}

As noted above, several hundreds of metres of sediment in the upper part of Ladegårdsåen Formation remain totally undated. However, some indication may be gained from subsequent events in the history of the Wandel Sea Basin.

Two occurrences in particular are pertinent in this context. Closely associated with the western fault block a fault-bound sequence of fully marine silty clay has been located (Rolle, in 


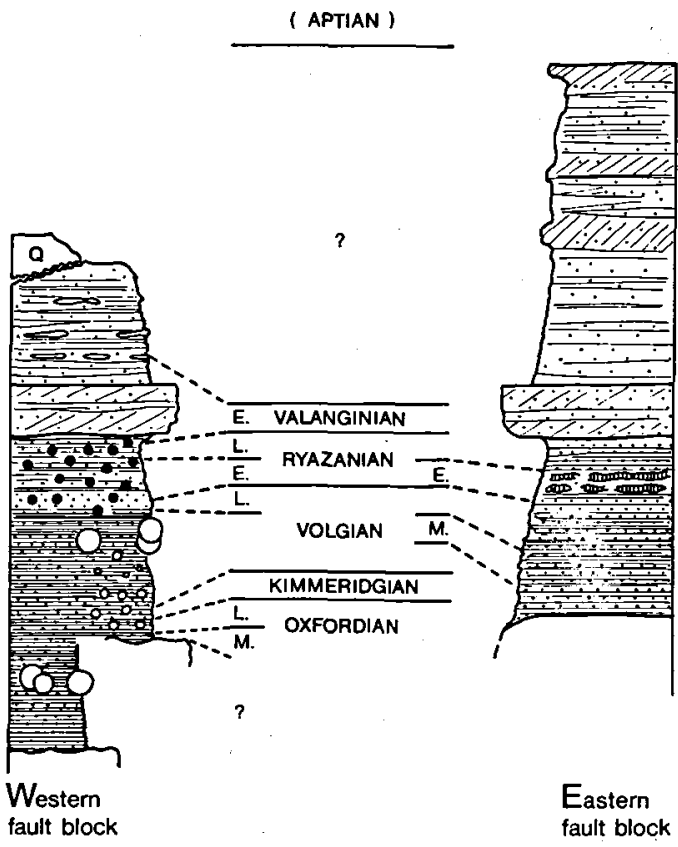

Fig. 4. Stratigraphy of the Ladegårdsåen Formation. (Note: the interval which may include Early Volgian strata has not been sampled).

press) which contains a well preserved Aptian dinoflagellate flora. Furthermore, at Kap Rigsdagen, some $45 \mathrm{~km}$ to the south, a sequence of lagoonal to coastal brackish and marine sediments of a similar age has been investigated (Håkansson et al. in press).

It appears, therefore, that the remaining part of the Ladegårdsåen Formation is confined entirely to the Early Cretaceous and, most probably, that the non-marine deposition was terminated prior to the Aptian.

Delayed appearance of Cretaceous dinoflagellates

Combined assemblage stratigraphy as developed in the present paper obviously improves the reliability of the age determinations and at the same time it provides a control of known age distributions. Thus, on the one hand the Buchia and ammonite faunas occur here fully in accord with established zonations. On the other hand, it is evident that typical Early Cretaceous dinoflagellates appear later relative to the ammonite and Buchia zonations in the Wandel Sea Basin than further south.
In the dinoflagellate floras of most regions so far investigated around the North Atlantic the Jurassic-Cretaceous turn-over is clearly seen in a number of characteristic species appearing in the latest Volgian - earliest Ryazanian, whereas their appearance is delayed to well into the Valanginian in the Wandel Sea Basin. It appears that a similar delay has been observed in northern Canada (Brideaux \& Fisher 1976, Tan \& Hills 1978, Brideaux \& McIntyre pers. comm.).

\section{Biogeography}

\section{Dinoflagellates}

The Middle Oxfordian dinoflagellates all belong to the widespread assemblages known from other northern regions (Svalbard, Andøya, East Greenland, and the Sverdrup Basin) as well as from NW Europe.

The Late Oxfordian - Early Valanginian dinoflagellate assemblage, however, deviates significantly from those of the North Atlantic region proper. The Peary Land assemblage during this period is dominated by long-ranging species, and a large number of species considered stratigraphically important in the Atlantic region are missing. Furthermore, the assemblage includes most of the species characterizing the 'borealis assemblage' from Arctic Canada. Brideaux \& Fisher (1976) described this assemblage as an 'extreme arctic' flora and recorded its distribution from the MacKenzie River delta to Ellef Ringness Island in the Sverdrup Basin. The existence of a comparable flora in Peary Land greatly strengthens the separate reality of this 'cold water' assemblage. So far, however, the 'borealis assemblage' has not been identified from Svalbard (except for one species), but this may be due to an apparant lack of cysts in sediments of comparable age (Bjærke in press).

The main species characterizing the 'borealis assemblage' have also been found in Late Oxfordian to Kimmeridgian sediments in Milne Land, East Greenland (Piasecki 1980). The composition of the Peary Land assemblage thus may indicate the presence of a zone of mixing between a 'true arctic' flora and a North Atlantic flora. A similar relationship between the 'borealis assemblage' and assemblages from more southern parts of Canada has apparently 
also been found by Brideaux \& McIntyre (pers. comm.).

During the Early Valanginian, the 'borealis assemblage' in Peary Land apparently was replaced completely by typical Early Cretaceous forms known from the entire North Atlantic region including NW Europe. The late appearance of Early Cretaceous forms may be related to a Valanginian temperature rise.

\section{Ammonites}

The earliest ammonite species from the Jurassic, the Middle Volgian Dorsoplanites gracilis, belongs to a genus that has its main occurrence in East Greenland, Siberia and the Russian Platform, but is also known from the Sverdrup Basin, Svalbard, Franz Josef Land, Andøya, and, very rarely, England. The species is known only from Greenland, the Sverdrup Basin (?), and Siberia.

The Late Volgian genus Craspedites is known mainly from the Russian Platform. Occurrences in northern Siberia (Shulgina 1969), Subarctic Urals (Saks 1972), Svalbard (Pchelina 1967; Ershova 1969) and the Sverdrup Basin (Jeletzky 1966) have been partly referred to Craspedites s. str., and partly to the slightly later Taimyroceras (for example all the Canadian occurrences).

Occurrences of $C$. okensis outside the Russian Platform, in northern Siberia and Svalbard, are rare and the material described up to now is not too well preserved. The Greenland occurrence does not solve the question whether $C$. okensis s. str. is endemic on the Russian Platform or whether it has a wider distribution.

The Early Ryazanian ammonite genus Borealites is also known primarily from northern regions (Sverdrup Basin, Svalbard?, Northern and Western Siberia), but has also been found in England. The Late Ryazanian genus Peregrinoceras, on the other hand, has been recorded from the Mangyshlak Peninsula (Transcaspia), the Volga region, and eastern England (Casey 1973). Casey suggested that Peregrinoceras may be "a southern variant or dimorph of Tollia". Nevertheless, the high artic occurrence here described seems to indicate that the previous lack of this genus in other northern regions is due to collection failure rather than to provincialism.

Neotollia from the Valanginian is very close to Tollia, which is widespread in the Boreal and
Sub-Boreal provinces from Arctic Canada, Svalbard, Siberia to England and NW Germany.

\section{Buchia}

All the Buchia species from Peary Land have a wide distribution in the Boreal province from Arctic Canada to Svalbard and the northern USSR. In addition, some are fairly common in the Sub-Boreal province (e.g. B. volgensis) and a few of them are even known from Alaska, British Columbia and California or have close allies in those areas (e.g. B. fischeriana, B. okensis, $B$. russiensis).

\section{Conclusions}

As a whole, the Peary Land assemblages are well correlated with those in other basins around the present Arctic Ocean; and they extend our knowledge of the distribution of East Greenland Late Jurassic-Early Cretaceous assemblages to the north.

It is especially noteworthy that a discrete hyperboreal planktic flora came into existence late in the Jurassic and that this 'cold water' assemblage prevailed well into the Valanginian, showing no trace of the turnover at the JurassicCretaceous boundary further sourth. This diachronism in the introduction of planktic floras in adjacent basins has a strong bearing on evaluation of age-relations.

Description of the ammonites (T.B.)

Genus Dorsoplanites Semenov, 1898

Dorsoplanites gracilis Spath, 1936

Pl. 1, figs. 1-2.

1936 Dorsoplanites gracilis Spath, p. 72, pl. 27, figs. 1a,b; pl. 28, figs. 3a-b; pl. 29, figs. 2a-b; pl. 30 figs. $2 a-b ;$ pl. 32 , figs. $2 a-b, 5 a-b ;$ pl. 33 , figs. 3-6; pl. 35, fig. 3 .

?1966 Dorsoplanites cf. gracilis Spath; Jeletzky, p. 21 , pl. 8 , figs. 10a-b, 11a-b.

1966 Dorsoplanites gracilis Spath; Mikhailov, p. 24, pl. 6, figs. 1-2; pl. 7, fig. 2; text-fig. 8 .

Material: 2 specimens from the Middle Volgian of loc. 5 (fig. 1). MGUH 15265 from GGU 196192 and MGUH 15266 from GGU 196193. 
Description: The largest specimen is $80 \mathrm{~mm}$ in diameter and the umbilical ratio is $41 \%$, while the umbilical ratio of the smaller nucleus is $44 \%$. Ribbing is fine and ribs fairly weak. Ratio of primaries to secondaries is $1: 1-2$ on early whorls and increases to 1:2-3 on later whorls. Constrictions are present in both specimens, but most distinct in the smaller one. The constrictions are more projected than the ribbing. No suture lines are preserved.

Discussion: A wide range of varieties of $D$. gracilis was figured by Spath (1936). Rich collections from the type area of this species in Milne Land (East Greenland) have since then been made and the specimens here described are well within the variation of the species. The similarity is particularly close between the smaller specimen described here and the specimen figured by Spath (1936, pl. 26, fig. 5) from Krebsedal ('Crab Valley'). The specimens figured by Mikhailov (1966) from Siberia are also very similar.

\section{Genus Craspedites Pavlow, 1892}

Craspedites cf. okensis (d'Orbigny, 1845)

Pl. 1, figs. 3-5.

1845 Ammonites okensis d'Orbigny, p. 436, pl. 34 , figs. $15-17$.

1911 Craspedites okensis (d'Orbigny); Douvillé, p. $213^{\mathrm{a}}$, pl. 213 , figs. $\mathrm{C}^{1}, \mathrm{C}^{\mathrm{a}}$.

? 1969 Craspedites okensis (d'Orbigny); Shulgina, p. 138 , pl. 26 , figs. 1,3 ; pl. 27 , figs. 1,2 ; pl. 38 , figs. 1,2 ; pl. 29 , figs. 4,5 .

?1969 Craspedites (Craspedites) okensis (d'Orbigny); Ershova, p. 56, pl. 1, fig. 1; pl. 2, fig. 1; pl. 3 , figs. 1-3; text-fig. 1 .

Material: 4 fragments from the Late Volgian of loc. 7 (fig. 1). MGUH 15267-15269 from GGU 196316.

Description: The best preserved specimen (pl. 1, fig. 3) shows a deep, rather narrow umbilicus with gently rounded umbilical shoulder and a smooth surface. Other fragments show very weak, hardly discernible ribs curved very slightly forward ventrally. The ribs may be slightly weaker on the venter than on the flanks, and they are not developed on the umbilical part of the flanks, umbilical shoulder and -wall. A small fragment has preserved part of the external suture-line, showing the ventral lobe, and 1st and 2 nd lateral lobes, all only slightly incised. Auxiliaries are not preserved.

Discussion: Those characteristic features which are preserved indicate a close similarity to the type-species of the genus Craspedites, C. okensis (d'Orbigny). Jeletzky (1966, p. 5) formally designated the larger of the two specimens figured by d'Orbigny (1845, p. 34, figs. 15-16) as lectotype, referring the smaller specimen (pl. 34 , figs. 13-14) to another species, as already pointed out by Nikitin $(1884$, p. $78-79)$.

Craspeditids from Boreal regions (northern Siberia, Subarctic Ural, Sverdrup Basin, Svalbard) have been divided into two subgenera: Craspedites s. str. and Taimyroceras Bodylevsky, 1956 (Jeletzky 1966; Shulgina 1969; Saks 1972). Taimyroceras seems to represent late craspeditids with weakened or completely interrupted ribs on the ventral side, but all intermediate stages occur (see Jeletzky 1966). The fragments from Greenland are closest to Craspedites s. str.

Genus Borealites Klimova, 1969

Borealites sp. aff. fedorovi Klimova, 1969

Pl. 1. fig. 6; pl. 2, figs. 1-2.

1969 Borealites fedorovi Klimova, p. 129, pl. 1, figs. $1-5$

1972 Borealites radialis Klimova, in Saks p. 195, pl. 35, figs. 1-2.

Material: 3 specimens have been identified from the Early Ryazanian of loc. 4 (fig. 1). MGUH 15270 from GGU 196333, MGUH 15271 from GGU 196332, MGUH 15272 from GGU 196333.

Description: The most complete specimen shows the slightly crushed, nearly complete body chamber and the youngest part of the phragmocone. The diameter of this specimen is $\mathbf{1 1 6}$ $\mathrm{mm}$, the diameter at the last suture $95 \mathrm{~mm}$, the length of the body chamber nearly $360^{\circ}$, and the umbilical ratio c. $33 \%$. The cross-section is compressed, but degree of compression is uncertain because the specimen is crushed. The fragment in pl. 2, fig. 2 shows that the sculpture of the 
inner whorls consists of bifurcating ribs; with increasing shell diameter (about $60 \mathrm{~mm}$ ) the ribs trifurcate and a little later the primaries strengthen and intercalatory ribs appear. The secondaries have a very weak forward bend to a diameter of at least c. $65 \mathrm{~mm}$. The sculpture of the younger part of the phragmocone consists of strong and sharp primaries, starting a short distance from the umbilical seam and continuing to the middle of the flanks, where they fade out. 4 5 secondaries per primary are developed at this stage. On the body chamber the number of secondaries increases to 5-6 per primary with no ventral bend. The middle of the flanks now tend to become smooth between the primaries and the secondaries, especially on the youngest part of the shell. The sutures are poorly preserved; they are slightly ascendent and fairly simple.

Discussion: The genus Borealites Klimova, 1969 is closely related to Pseudocraspedites Casey, Mesezhnikov \& Shulgina, 1977 (type species Subcraspedites anglicus Shulgina, in Saks 1972), Peregrinoceras (type species Olcostephanus pressulus Bogoslovsky, 1897) and to Ronkinites Shulgina, 1972 (type species Subcraspedites (Ronkinites) rossicus Shulgina, in Saks 1972). These forms are differentiated at generic or subgeneric level in the literature, but separation between some of them seems hard to justify. However, a taxonomic revision is beyond the scope of the present work; this must await a proper evaluation of intraspecific variability at all horizons. As a group these forms mark the transition from the ancestral Subcraspedites of the Upper Volgian to Surites of the Upper Ryazanian, but the exact relations may be in part complicated by provincialism.

According to Casey (1973) and revisions in Casey, Mesezhnikov \& Shulgina (1977), the genus Borealites includes the following species: B. fedorovi Klimova, 1969 (type species), $B$. radialis Klimova, 1972, B. mirus Klimova, 1972, B. explicatus Klimova, 1972 (all in Saks 1972) and $B$.? suritiformis Klimova (in Golbert et al., 1972), all from the same place and horizon in Western Siberia; Subcraspedites (Borealites) suprasubditus (Bogoslovsky sensu Shulgina, 1972 (in Saks 1972) of Northern Siberia; ?Subcraspedites (Borealites) : aff. suprasubditus (Bogoslovsky) from East Greenland, described by Surlyk (1973); Taimyroceras ?bodylevskyi Voronets, 1962 and Subcraspedites ex. gr. bidevexus Bogoslovsky, both described by Voronets (1962) from the Lena-Anabar Region; and Praetollia antiqua Jeletzky, 1973 from Arctic Canada.

Various other forms from Svalbard, Novaya Zemlya and Arctic Canada have also been referred at times to Borealites, but the specimens from Greenland are closest to the "species" described by Klimova from Western Siberia, which all seem to be very similar. The shape and a slight forward bend of the ribs on the inner whorls relate the Greenland specimens to the type-species, $B$. fedorovi, while they are closer to $B$. radialis in size and the ribbing pattern of the last whorls. B. suprasubditus (Bogoslovsky) sensu Shulgina, 1972 (in Saks 1972) from Northern Siberia is also close, but seems to differ by having less thickened primaries in the late stages of growth.

Species belonging to Pseudocraspedites differ primarily in their finer ribbing and by having more secondaries in relation to primaries on the younger part of the shell, and species belonging to Peregrinoceras by their finer and more fasciculate ribbing. Ronkinites is characterized by abundant, deep constrictions, absence of thickened primary ribs on adult whorls, a smaller number of secondary ribs per primary rib on adult whorls and less curvature of the ribs on the venter.

\section{Genus Peregrinoceras Sazonova, 1971}

Peregrinoceras sp. aff. albidum Casey, 1973

Pl. 3, figs. 1-3

1973 Peregrinoceras albidum Casey, p. 256, pl. 10 , figs. $1,8 \mathrm{a}-\mathrm{b}$; figs. $6 \mathrm{~g}-\mathrm{h}$.

Material: One well preserved specimen (MGUH 15273 from GGU 196352) and a few fragments which may belong to the same species (MGUH 15274-15275 from GGU 196351) from the Late Ryazanian just NW of loc. 4 (fig. 1).

Description: The only well preserved specimen shows the phragmocone and a part of the body chamber. The diameter of the phragmocone is $43 \mathrm{~mm}$ and the umbilical ratio $31 \%$. The very well preserved umbilicus exposes the low expan- 
sion rate of the early whorls characteristic of the genus. The outer whorl of the phragmocone has a sub-rectangular broad-ventered cross-section. It is slightly compressed, whorl height and width being $18.5 \mathrm{~mm}$ and $15.5 \mathrm{~mm}$ respectively at the last suture. The inner whorls exposed in the umbilicus show strong primary ribbing beginning a short distance from the umbilical seam. The outer whorl of the pragmocone shows characteristic fasciculate, nearly virgatotome ribbing with primaries dividing into 3-4 secondaries on the middle of the flanks. On the venter the secondaries form a distinct but rather weak forward bend.

The fragments shown in pl. 2, figs. 2-3 are with some doubt referred to the same species. The ribbing of these specimens is slightly coarser and the cross-section more rectangular.

Discussion: After much previous discussion on the taxonomic position of Olcostephanus pressulus Bogoslovsky, 1897 and $O$. subpressulus Bogoslovsky, 1897 from the Russian Platform, Sazonova (1971) referred them to the new genus Peregrinoceras with the type-species $O$. pressulus, adding further new species $P$. bellum and $P$. ramosum from the same area. The genus has since then been described from Eastern England by Casey (1973). He created two new species, $P$. albidum and $P$. rosei, and also referred a number of species established by Neale (1962) to this genus ( $P$. prostenomphaloides, $P$. wrighti, $P$. pseudotolli and $P$. sp. nov.). The precise relation of Peregrinoceras to its contemporaries remains to be evaluated.

The specimens from Greenland show all the characteristics of the genus: the tolline inner whorls, the slightly quadrangular whorl section, the distinct but not very strong, linguiform bend of the ribs ventrally, and the fasciculate ribbing. They seem to be closest to Peregrinoceras albidum Casey, 1973 in shape and sculpture. The very well-preserved umbilicus of the specimen figured in pl. 3 , fig. 1 shows a remarkable similarity to $P$. bellum Sazonova (1971, pl. 6, fig. 2).

\section{Genus Neotollia Shulgina, 1969}

\section{Neotollia sp.}

Pl. 3, fig. 4
Material: One specimen from the Early Valanginian of loc. 2 (fig. 1). MGUH 15276 from GGU 196345.

Description: The only specimen consists of an impression of the inner whorls. It shows a rather deep and narrow umbilicus with fine primaries exposed on the inner whorls. On the outer whorl the ribs bifurcate about the middle of the sides. They are nearly straight on the flanks and directed forward at an acute angle to the radius. A small fragment of the venter exposes a forward bend of the ribs ventrally.

Discussion: It is hard to see any systematic differences worthy of generic rank between Tollia Pavlov, 1914 and Neotollia, as exemplified by the amplified interpretation of Shulgina in Saks (1972), and some authors, e.g. Jeletzky (1979), regard the genus as synonymous with the genus Tollia.

On the basis of a ribbing pattern similar to that of the type-species of Neotollia, N. klimovskiensis Shulgina, 1969 the fragment is referred to that genus.

Notes on the Buchia species (V.Z.)

Buchia russiensis (Pavlov, 1907)

Pl. 3, figs. 5-6.

Material: 2 specimens from the Middle Volgian of loc. 5 (fig. 1).

B. russiensis is widespread in the Middle Volgian shallow water, Boreal deposits in the USSR (Zakharov 1981), but it has not been recorded previously from Greenland. The specimens from Peary Land are reminiscent also of $B$. piochii from the Portlandian of northern Alaska (Imlay 1961, pl. 7, fig. 2), of B. elderensis from the Middle Tithonian of California (Jones et al. 1969, pl. 2, figs. 20-24 only), of $B$. piochii var. russiensis from the Late Portlandian of British Columbia (Jeletzky 1965, pl. 1, figs. 3 and 6), and of $B$. russiensis from the Volgian of Svalbard (Sokolov \& Bodylevsky 1931, pl. 1, fig. 2).

Buchia fischeriana (d'Orbigny, 1845)

Pl. 3, figs. 7-11 
Material: Several specimens from the Middle Volgian of loc. 5, and the Early Ryazanian of locs 4 and 5 (fig. 1).

B. fischeriana is widespread through most of the late Middle Volgian, the Late Volgian, and the earliest Ryazanian in USSR (Zakharov 1981), California (Anderson 1945, Jones et al. 1969), British Columbia (Jeletzky 1965), and Arctic Canada (Jeletzky 1966). Although not all specimens from Peary Land can be definitely identified, the full known stratigraphic range of the species is represented here.

Buchia unschensis (Pavlov, 1907)

Pl. 4, figs. 1-2.

Material: Several specimens from the Late Volgian of loc. 7 and quite abundant in the Early Ryazanian of locs 4 and 5 (fig. 1).

B. unschensis has not been recorded previously from Greenland. However, the specimens from the $H$. kochi Zone and the Praetollia beds illustrated by Spath (1947) as B. volgensis undoubtedly should be referred to $B$. unschensis.

$B$. unschensis is widespread in the Boreal (mainly arctic) deposits of the Craspedites subditus and $H$. kochi Zones, but occurs most abundantly in the Jurassic-Cretaceous transitional beds in northern Siberia, the Petchora River region, Svalbard, and, probably, in Arctic Canada (Jeletzky 1966, Mesezhnikov et al. 1977, 1979, Zakharov 1981). The time-range of the Peary Land occurrences, in general, is in accordance with the range typical of the species. However, the youngest specimen (pl. 4, fig. 2) probably originated slightly above the $H$. kochi Zone and has a flatter right valve reminiscent of $B$. okensis.
Buchia cf. terebratuloides (Lahusen, 1888)

Pl. 3, fig. 12.

Material: Several specimens from the Late Volgian of loc. 7 and the Early Ryazanian of locs. 4 and 5 (fig. 1).

The Peary Land material is in general poorly preserved and does not allow definite determinations. The stratigraphic range is in accordance with the distribution elsewhere in the Boreal region (Zakharov 1981).

Buchia okensis (Pavlov, 1907)

Pl. 4, figs. 3-8; pl. 5, figs. 1-3.

Material: Several specimens have been identified from the $H$. koch $i$ Zone of locs 4 and 5 fig. 1).

Representatives of $B$. okensis are widespread in the Ryazanian of both northern Eurasia and northern North America. According to most authors the appearance of $B$. okensis indicates the beginning of the Cretaceous. However, the species is not found in the Chetaites sibiricus Zone or its time equivalent, the Praetollia maynci Zone (cf. Surlyk 1978), in the Petchora and Chatanga River sections in northern USSR. Here $B$. okensis appears first at the base of the H. kochi Zone, while the last rare specimens occur in the Surites analogus Zone (Zakharov 1981). No representatives of $B$. okensis have been found in the $B$. mesezhnikowi Zone.

In Peary Land the species is apparently restricted to the $H$. kochi Zone. In addition to adult specimens most concretions contain a number of typical young forms (pl. 4, figs. 3-6) and abundant unidentifiable juveniles. Some of the young specimens of $B$. okensis (e.g. pl. 4, fig.

PLATE 1

Figs. 1-2: Dorsoplanites gracilis Spath, 1936. Middle Volgian 1a-b: lateral view of internal and external cast (1b rubber cast), MGUH 15265. from GGU 196192; 2a-c: lateral and ventral views, MGUH 15266 from GGU 196192:

Figs. 3-5: Craspedites cf. okensis (d'Orbigny, 1845). Upper Volgian. 3: lateral view of rubber cast of umbilicus and ?early part of body chamber, MGUH 15267 from GGU 196316; 4a-d: ventral and lateral view of fragment of phragmocone and 3x enlarged ventral and lateral views showing suture line, MGUH 15268 from GGU 196316; 5: fragment of body chamber, MGUH 15269 from GGU 196316.

Fig. 6: Borealites sp. aff. fedorovi Klimova, 1969, fragment of body chamber, Early Ryazanian, MGUH 15270 from GGU 196333. Plate 1-5: All figures natural size unless otherwise indicated. 

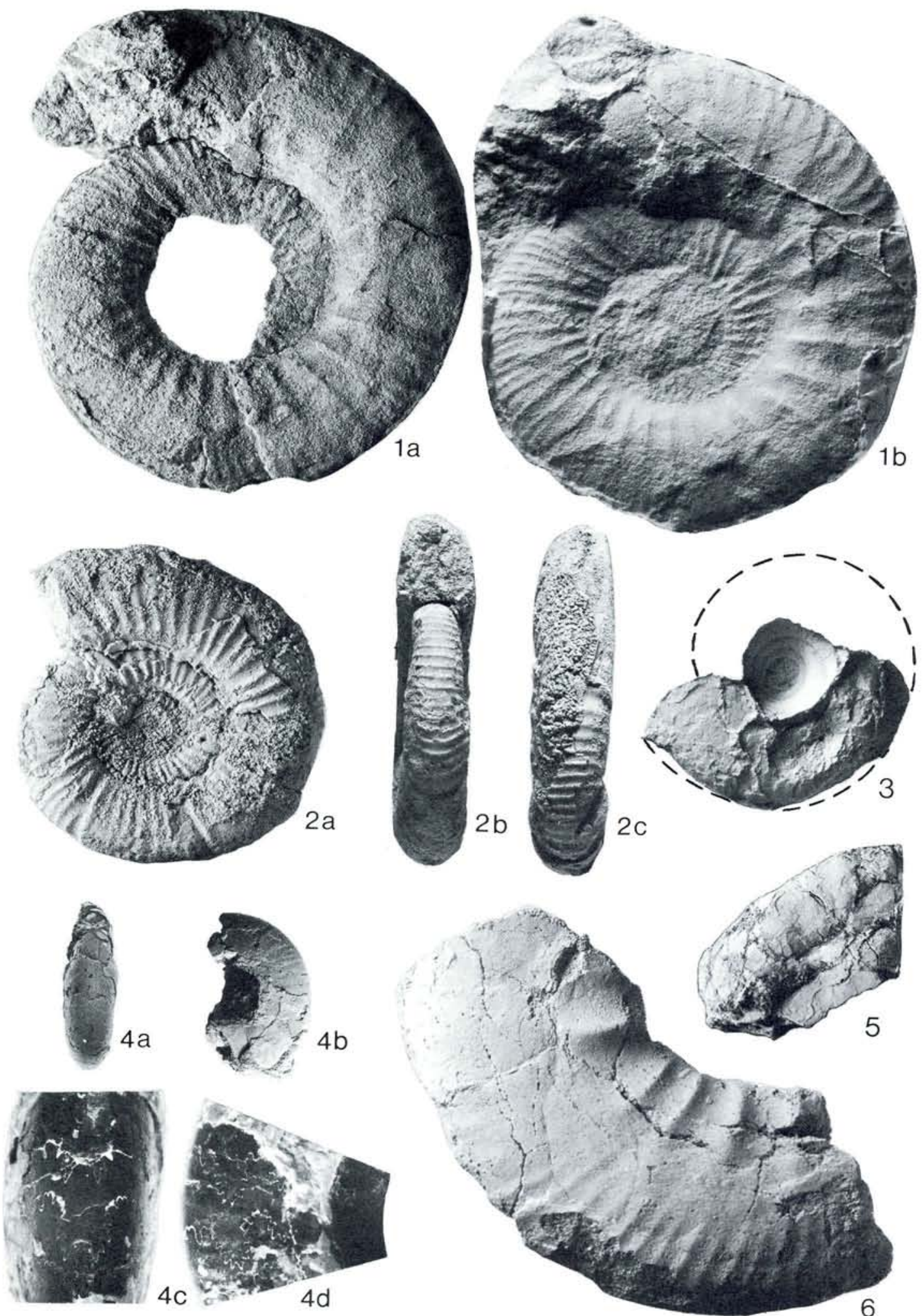
6) are virtually identical to young forms from the H. kochi Zone in northern Siberia (Zakharov 1981, pl. 27, figs. 1-2). The right valve of another specimen (pl. 4 , fig. $3 \mathrm{a}$ ) is very similar to $B$. subokensis from the Berriasian of northern Alaska and to a specimen of $B$. okensis from the Early Berriasian of British Columbia (Jeletzky 1965, pl. 4, fig. 62).

Buchia volgensis (Lahusen, 1888)

P1. 5, figs. 4-5.

Material: Several specimens from the $H$. kochi Zone of loc. 4 (fig. 1).

B. volgensis is extremely common and widely distributed in the Boreal and Sub-Boreal Ryazanian deposits, particularly in the $S$. analogus Zone (Zakharov 1981). No representatives of $B$. volgensis have been found in the Valanginian. In northern USSR the species appears above the Jurassic-Cretaceous boundary, at the base of the H. kochi Zone. Earlier indications of the presence of this species in the Late Volgian of northern Siberia (in Saks 1972) appear to be erroneous and are based on misidentification of large specimens of B. unchensis (cf. Zakharov 1981, pl. 3, fig. 4). This seems to be valid also for North America (Jeletzky 1965). However, Surlyk (1978) indicated $B$. volgensis from the top of the Middle Volgian (Laugeites groenlandicus and Epilaugeites vogulicus Zones) of East Greenland. The left valves, which are dominant in Surlyk's collection, are closely comparable to $B$. volgensis (cf. Surlyk 1978, pl. 2, fig. 3), whereas the right valves show some resemblance to the B. russiensis - B, fischeriana group (cf. Surlyk 1978, pl. 4, fig. 8). Further study of the material from East Greenland is necessary in order to solve this problem.

Buchia sp. indet. cf. keyserlingi (Lahusen, 1888) Pl. 5, fig. 6.

Material: A single specimen from the Valangi- nian of loc. 2 (fig 1 ) is referred with reservation to this species.

B. keyserlingi is restricted to the Valanginian. The isolated specimen from Peary Land is probably a young specimen.

List of dinoflagellate cysts (S. P.)

The species are arranged alphabetically. The ranges recorded in the Ladegårdsåen Formation are indicated for each species in the list. Most samples are dated by ammonites or Buchia; brackets around an age indicate that dating is based on dinoflagellate cysts only.

Most systematic references are cited in Stover \& Evitt (1978); exceptions are included in the present reference list.

Ambonosphaera sp. (Piasecki, 1980): Pl. 6, fig. 8.

One specimen (Late Oxfordian).

Biorbifera sp.

One specimen. Middle Volgian.

Cleistosphaeridium sp.: Pl. 7, fig. 7.

Ryazanian - Early Valanginian.

Fromea sp.

One specimen. Early Ryazanian.

Gonyaulacysta helicoidea (Cookson \& Eisenack) Sarjeant, 1966: Pl. 7, figs. 4-6.

Early Ryazanian - Early Valanginian.

Gonyaulacysta jurassica subsp. jurassica (Deflandre) Norris \& Sárjeant, 1965: (Middle Late Oxfordian).

Gonyaulacysta jurassica subsp. longicornis (Deflandre) Lentin \& Williams, 1973: Pl. 6, fig. 7. (Middle Oxfordian - Kimmeridgian).

Gonyaulacysta scarburghensis Sarjeant, 1964: Pl. 6, figs. 1-2. (Middle Oxfordian).

\section{PLATE 2}

Figs. 1-2: Borealites sp. aff. fedorovi Klimova, 1969. Early Ryazanian. 1a-d: lateral and ventral views, and rubber cast of umbilical part, arrow in 1a marks last suture, MGUH 15271 from GGU 196332; 2a-b: lateral and ventral view, MGUH 15272 from GGU 196333. 


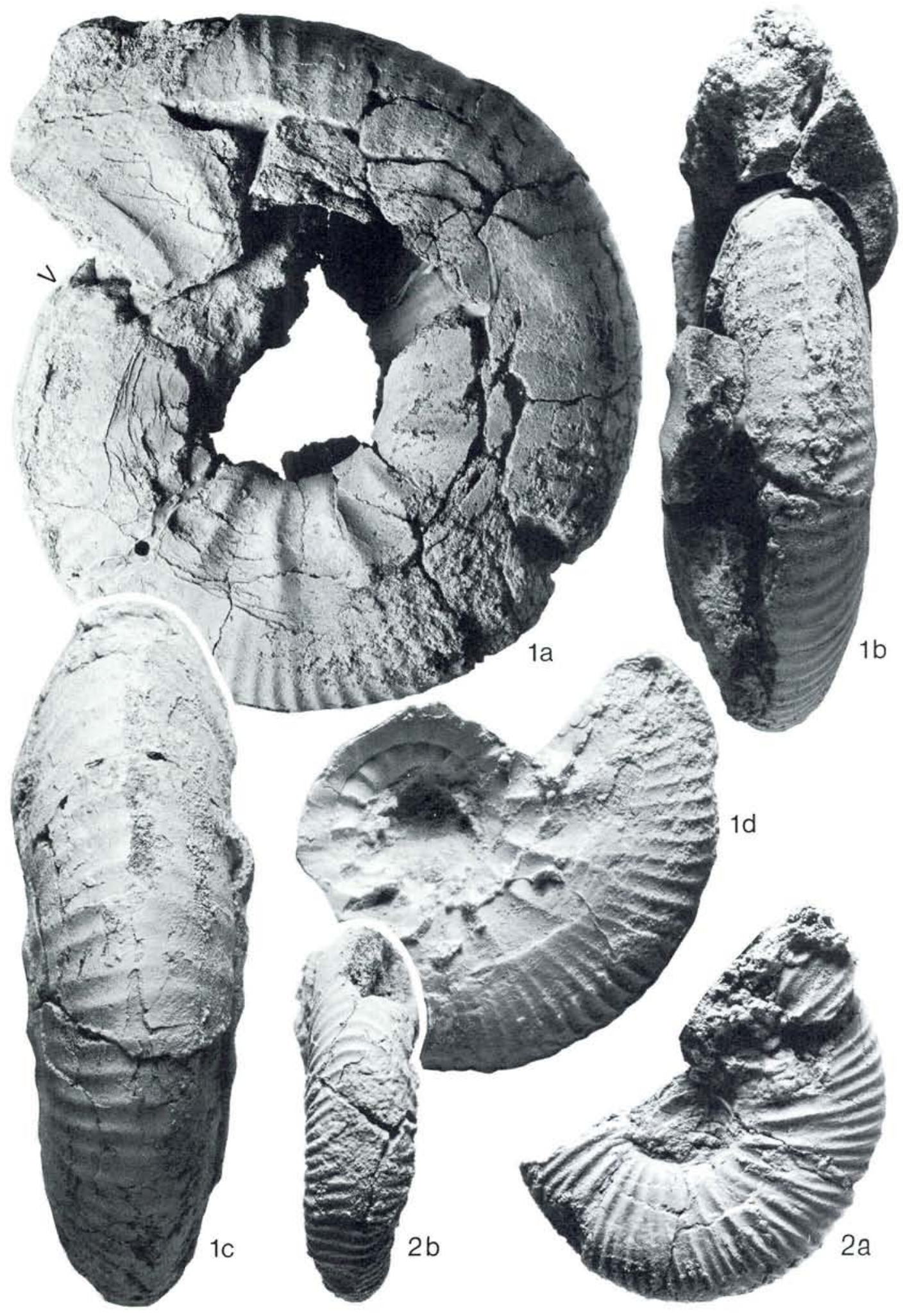


Gonyaulacysta sp. 1.: Pl. 7, figs. 1-3.

Middle Volgian.

Gonyaulacysta sp. 2.

One specimen. Early Ryazanian.

Gardodinium cf. ordinale (Davey, 1974).

One poorly preserved specimen. (Valanginian).

Gardodinium cf. trabeculosum ((Gocht) Alberti, 1961).

One poorly preserved specimen (Valanginian).

cf. Horologinella sp.

One specimen. Early Ryazanian.

Hystrichodinium voigtii (Alberti) Davey, 1974.

One specimen. Early Valanginian.

Hystrichogonyaulax cladophora (Deflandre)

Stover \& Evitt, 1978.

(Late Oxfordian - Kimmeridgian).

Hystrichogonyaulax aff. serrata ((Cookson \& Eisenack) Stover \& Evitt, 1978). Early Ryazanian.

Kalyptea diceras Cookson \& Eisenack, 1960.

One specimen. (Middle Oxfordian).

Lagenorhytis sp.

Early Ryazanian.

Lanterna saturnalis Brideaux \& Fisher, 1976: PI. 6, fig. 10. (Kimmeridgian).

Lanterna sp.

Middle Volgian
Leptodinium aff. hyalodermopsis ((Cookson \& Eisenack) Stover \& Evitt, 1978): Pl. 6, figs. 3-5. (Kimmeridgian) - Early Valanginian.

Muderongia tetracantha (Gocht) Alberti, 1961: Pl. 7, fig. 10. (Valanginian).

Oligosphaeridium complex (White) Alberti, 1961: Pl. 7, fig. 9. (Valanginian).

Oligosphaeridium sp.

One specimen. Early Valanginian.

Paragonyaulacysta borealis Brideaux \& Fisher, 1976: Pl. 6, fig. 6. (Late Oxfordian) - Early Valanginian.

Pareodinia ceratophora Deflandre, 1947.

(Kimmeridgian).

Pareodinia sp.

Early Ryazanian.

Perrisseiasphaeridium $\mathrm{sp}$.

One specimen. Early Ryazanian.

Pseudoceratium sp.

One specimen. (Valanginian).

Sentusidinium myriatrichum Fensome, 1979: PI. 6, fig. 9.

(Kimmeridgian) - Late Ryazanian.

Sentusidinium aff. rioultii ((Sarjeant) Sarjeant \& Stover, 1978). (Kimmeridgian).

Sentusidinium sp. 1.

Late Volgian - Early Ryazanian.

\section{PLATE 3}

Figs. 1-3: Peregrinoceras sp. aff. albidum Casey, 1973. Late Ryazanian. 1a-b: lateral and ventral view, MGUH 15273 from GGU 196352; 2a-b: lateral and ventral view of fragment of body chamber, MGUH 15274 from GGU 196351; 3a-b: lateral and ventral view of fragment of body chamber, MGUH 15275 from GGU 196351.

Figs. 4a-b: Neotollia sp., lateral view of external and internal (rubber) cast, Early Valanginian, MGUH 15276 from GGU 196345. Figs. 5-6: Buchia russiensis (Pavlow, 1907). Middle Volgian. 5: fragment of left valve, MGUH 15277 from GGU 196192; 6a-c: left valve, posterior view and right valve, MGUH 15278 from GGU 196192.

Figs. 7-11: Buchia fischeriana (d'Orbigny, 1845). 7: left valve, Middle Volgian, MGUH 15279 from GGU 196193; 8: left valve, Early Ryazanian, MGUH 15280 from GGU 196289; 9: right valve, Early Ryazanian, MGUH 15281 from GGU 196196; 10a-b: right and left valve, Early Ryazanian, MGUH 15282 from GGU 196197; 11a-b: right and left valve, Early Ryazanian, MGUH 15283 from GGU 196324.

Figs. 12a-b: Buchia ex. gr. terebratuloides (Lahusen, 1888), right and left valve, Late Volgian, MGUH 15284 from GGU 196316. 

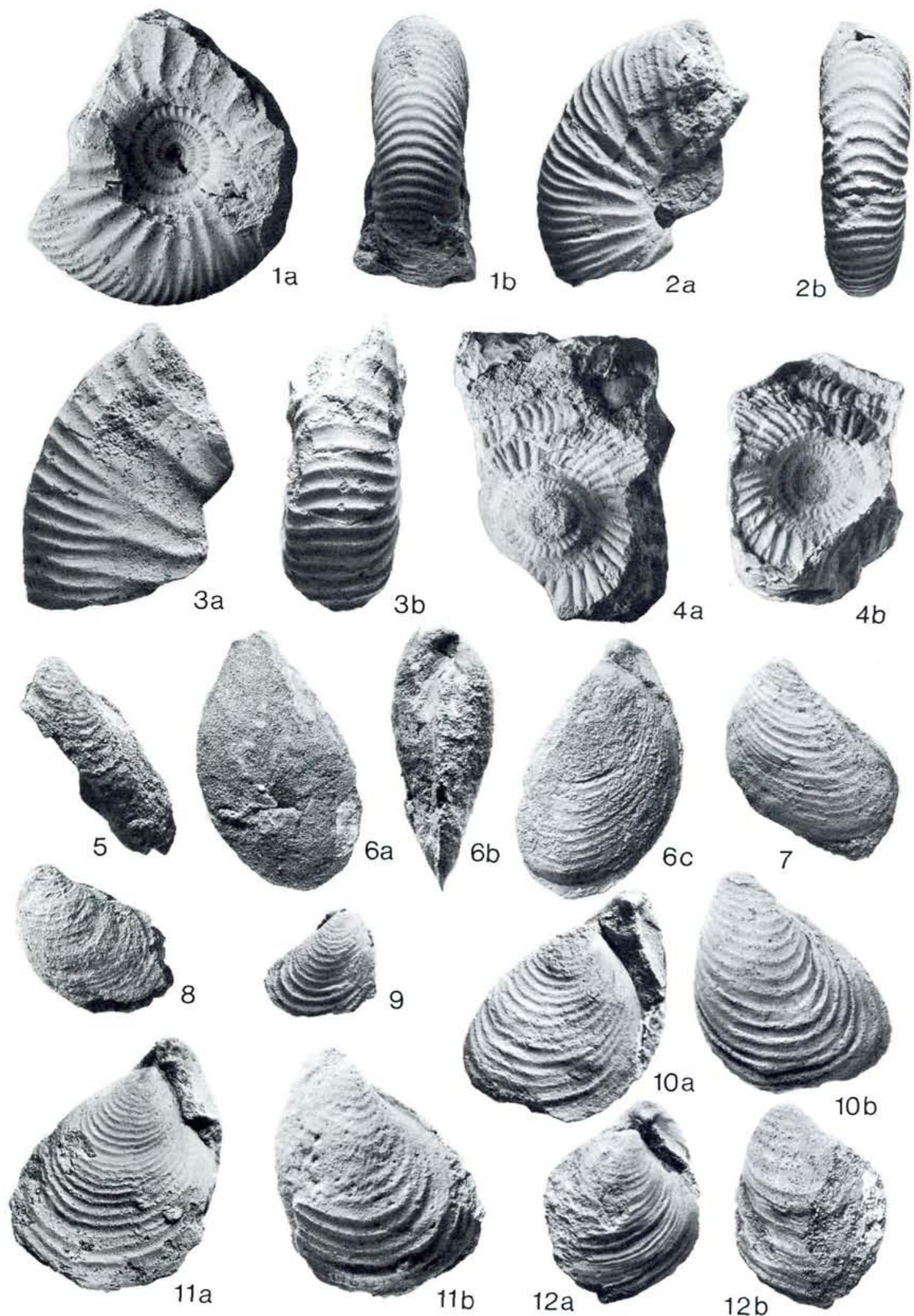
Sentusidinium sp. 2.

(Late Oxfordian).

Sirmiodinium grossii Alberti, 1961. (Middle Oxfordian - Valanginian).

Tanyosphaeridium isocalamus. (Deflandre \& Cookson) Davey \& Williams, 1969: PI. 7, fig. 8. Late Volgian - Early Valanginian.

Tubotuberella apatella (Cookson \& Eisenack) Ioannides, Stavrinos \& Downie, 1977. (Late Oxfordian) - Early Ryazanian.

Tubotuberella dangeardii (Sarjeant) Stover \& Evitt, 1978. (Kimmeridgian).

Tubotuberella egemenii (Gitmez) Stover \& Evitt, 1978. (Kimmeridgian).

Tubotuberella rhombiformis Vozzhennikova, 1967.

Late Volgian - Early Valanginian.

Valensiella ovula (Deflandre) Eisenack, 1963. (Late Oxfordian) - Early Ryazanian.

Valensiella cf. ampulla (Gocht, 1970). (Kimmeridgian).

Acknowledgements. We thank Henrik Egelund, Steen L. Jacobsen, Jan Aagaard, Inge Nyegaard, and Karen Nielsen for technical help. Richard Bromley improved the language and John Callomon provided helpful advice on the ammonites. The field work was carried out as part of the GGU mapping project 'North Greenland', and the work is published with the permission of the Director of the Geological Survey of Greenland.

\section{Dansk sammendrag}

Fossilførende øvre jura - nedre kridt aflejringer beskrives for første gang fra Nordgrønland. Dele af Wandel Sea Bassinet blev transgrederet $\mathrm{i}$ mellem oxfordien og forblev marint frem til valanginien, hvorefter udaterede limniske aflejringer er fremherskende. Lagseriens indhold af dinoflagellater, ammoniter og Buchia viser tilstedeværelse af mellem og øvre oxfordien, kimmeridgien, mellem og øvre volgien, nedre og øvre ryazanien samt nedre valanginien. Både dinoflagellat floraen og mollusk faunaen viser nært slægtskab med tilsvarende forekomster i Sverdrup Bassinet, Svalbard og det nordlige USSR. De demonstrerer yderligere nogen forbindelse til mere sydlige, boreale og sub-boreale aflejringer i Østgrønland, England, den Russiske Platform samt - i mindre omfang - Nordamerika.

En integreret dinoflagellat-ammonit-Buchia stratigrafi viser at nedre kridt dinoflagellat floraen viser sig senere $\mathrm{i}$ Wandel Sea Bassinet end $i$ mere sydlige aflejringsområder. Det fremgår endvidere at en distinkt "jurassisk" dinoflagellat flora trivedes en vis tid ind $i$ nedre kridt helt upåvirket af det generelle skift ved jura-kridt grænsen.

\section{References}

Anderson, F. M. 1945: Knoxville series in the California Mesozoic. Bull. Geol. Soc. 'Am. 56(10), 909-1014.

Birkelund, T., Callomon, J. H. \& Fürsich, F. T. 1978a: The Jurassic of Milne Land, central East Greenland. Rapp. Grønlands Geol. Unders. 90, 99-106.

Birkelund, T., Thusu, B. \& Vigran, J. 1978b: Jurassic-Cretace-' ous biostratigraphy of Norway, with comments on the British Rasenia cymodoce Zone. Palaeontology 21(1), 3163.

Bjærke, T. in press: Mesozoic palynology of Svalbard V. Dinoflagellates from the Agardhfjellet Member (Middle and Upper Jurassic) in Spitsbergen. Norsk Polarinst, Skr.

Bodylevsky, V.I. 1956: The new genus Taimyroceras from Northern Siberia. Mater. Pal. Nat. Geol. Inst. (VSEGEI), Series "New families and genera" 12, 82-84. (In Russian).

Bogoslovsky, N. A. 1897: Der Rjasan-Horizont, seine Fauna, seine stratigraphischen Beziehungen und sein wahrscheinliches Alter. Mater. Geol. Ross. 18, 158 pp.

Brideaux, W. W. \& Fisher, M. I. 1976: Upper Jurassic Lower Cretaceous dinoflagellate assemblages from Arctic Canada. Bull. Geol. Suv. Can. 159, 53 pp.

Callomon, J. H. \& Birkelund, T, 1980: The Jurassic transgression and the mid-late Jurassic succession in Milne Land, central East Greenland. Geol. Mag. 117 (3), 211-310.

Casey, R. 1973: The ammonite succession at the Jurassic-Cretaceous boundary in eastern England. In Casey, R. \& Rawson, P. F. (eds) The Boreal Lower Cretaceous. Geol. J. Spec. Iss. 5, 193-266.

Casey, R., Mesezhnikov, M. S. \& Shulgina, N. I. 1977: Correlation of the boundary deposits of the Jurassic and Cretaceous of England, Russian Platform, the Sub-Polar Urals and Siberia. Akademia Nauk SSSR, Ser. Geol. 1977, 7, 14-33 (In Russian).

Christie, R. L. 1979: The Franklinian geocyncline in the Canadian Arctic and its relationship to Svalbard. Norsk Polarinst. Skr. 167, 263-314.

PLATE 4

Figs. 1-2: Buchia unschensis (Pavlov, 1907). 1a-d: right valve, left valve, posterior and anterior view, Early Ryazanian, MGUH 15285 from GGU 196196; 2a-d: right valve, left valve, posterior and dorsal view, Ryazanian, MGUH 15286 from GGU 196350. Figs. 3-8: Buchia okensis (Pavlov, 1907). Early Ryazanian. 3a-c: right valve, left valve and posterior view, MGUH 15287 from GGU 193333; 4a-c: right valve, left valve and anterior view, MGUH 15288 from GGU 196333; 5a-c: right valve, posterior view and left valve, MGUH 15289 from GGU 196333; 6a-c: right valve, left valve and posterior view, MGUH 15290 from GGU 196196; 7: right valve, MGUH 15291 from GGU 196333; 8: right valve, MGUH 15292 from GGU 196332. 

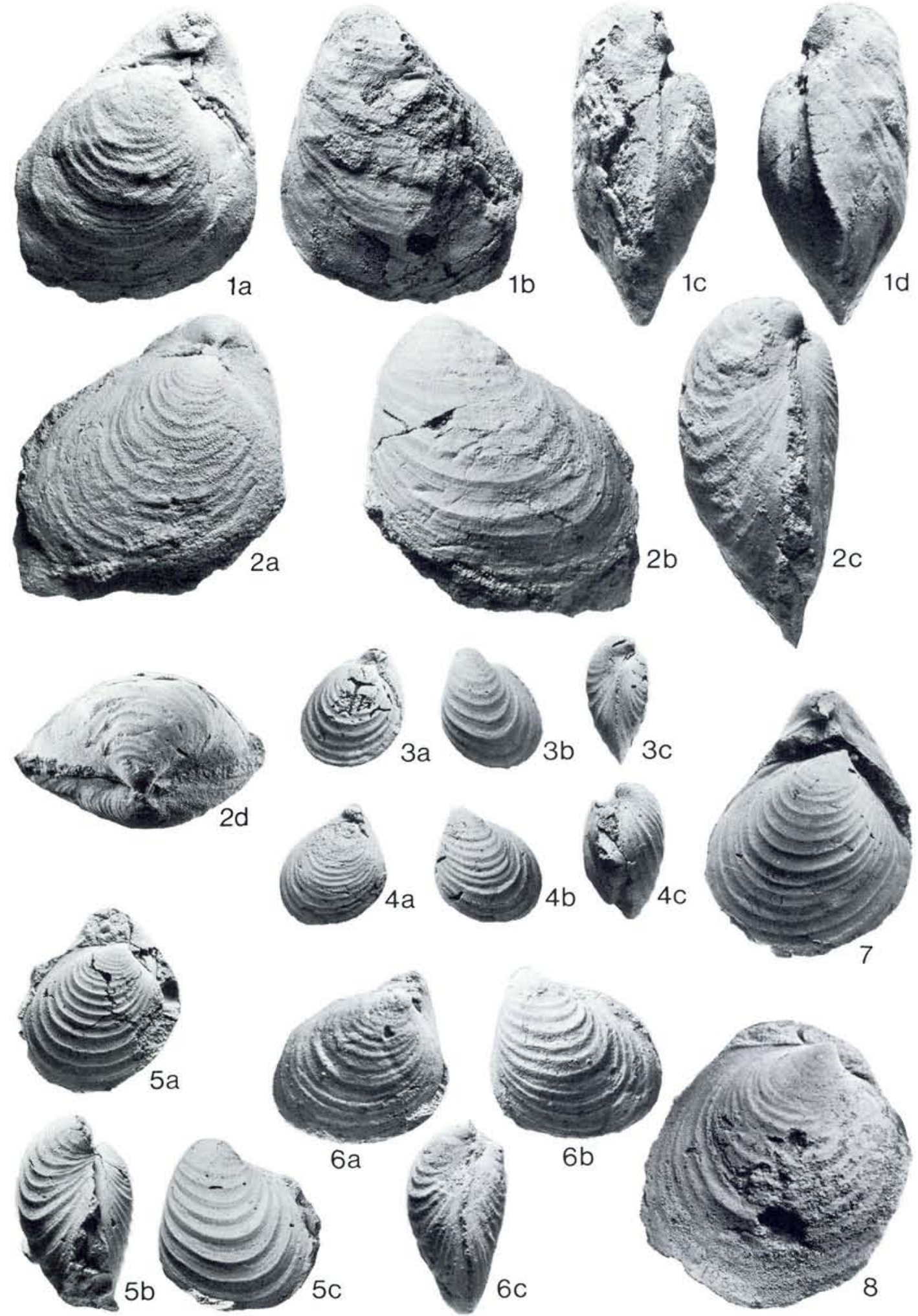
Dawes, P. \& Soper, J. 1973: Pre-Quaternary history of North Greenland. AAPG Mem. 19, 117-134.

Dawes, P. 1976: Precambrian to Tertiary of northern Greenland. In Escher, A. \& Watt, W. S. (eds) Geology of Greenland, 249-303. Geol. Surv. Greenland.

Douvillé, R. 1911: Palaeontologia Universalis, 213, 213

Duxbury, S. 1979: On Lagenorhytis Duxbury nom. nov. Taxon $28,587$.

Ershova, E. S. 1969: New finds of Late Volgian ammonites in Vestspitsbergen. Uch. zapniega paleont. i. biostrat. 26, 52-69. (In Russian).

Fensome, R. A. 1979: Dinoflagellate cysts and acritarchs from the Middle and Upper Jurassic of Jameson Land, East Greenland. Bull. Gronlands geol. Unders. 105, $76 \mathrm{pp}$.

Golbert, A. V., Klimova, I. G., Saks, V. N. \& Turbina, A. S. 1972: New data on the stratigraphy of the Lower Cretaceous in Western Siberia. Geol. Geofs. 5, 1-17 (In Russian).

Hallam, A. 1978: Eustatic cycles in the Jurassic. Palaeogeogr. Palaeoclimat., Palaeoecol. 23, 1-32.

Harland, W. B. 1965: A symposium on continental drift: V. Discussion. Phil. Trans. R. Soc. 258, 59-75.

Harland, W. B. 1969: Contribution of Spitsbergen to understanding of tectonic evolution of North Atlantic region. AAPG Mem. 12, 817-851.

Håkansson, E. 1979: Carboniferous to Tertiary development of the Wandel Sea Basin, eastern North Greenland. Rapp. Gronlands geol. Unders. 88, 73-83.

Håkansson, E. \& Heinberg, C. 1977: Reconnaissance work in the Triassic of the Wandel Sea Basin, Peary Land, eastern North Greenland. Rapp. Gronlands geol. Unders. 85, 1115.

Håkansson, E., Heinberg C. \& Stemmerik, L. in press: The Wandel Sea Basin from Holm Land to Lockwood $\emptyset$, eastcrn North Greenland. Rapp. Gronlands geol. Unders.

Håkansson, E. \& Pedersen, S. S. 1981: Late Paleozoic to Paleogene development of the continental margin in North Greenland. Abstract. 3rd Inst. Symp. Arctic Geol.

Imlay, R. W. 1961: Characteristic Lower Cretaceous megafossils from northern Alaska. Prof. Pap. U. S. geol. Surv. $335,74 \mathrm{pp}$.

Jeletzky, J. A. 1965: Upper Jurassic and Early Cretaceous fossil zones of the Canadian Western Cordillera, British Columbia. Bull. Geol. Surv. Can. 103, 70 pp.

Jeletzky, J. A: 1966: Upper Volgian (latest Jurassic) ammonites and Buchia of Arctic Canada. Bull. Geol. Surv. Can. $128,51 \mathrm{pp}$.

Jeletzky, J. A. 1973: Biochronology of the boreal latest Jurassic, Berriasian and Valanginian in Canada. In Casey, R. \& Rawson, P. F. (eds) The Boreal Lower Cretaceous. Geol. J. Spec. Iss. 5, 41-80.

Jeletzky, J. A. 1979: Eurasian craspeditid genera Temnoptychites and Tollia in the Lower Valanginian of Sverdrup Basin, district of Franklin. Bull. Geol. Surv. Can. 299, 89 pp.

Johnson, C. D. \& Hills, L. V. 1973: Microplankton zones of the Savik Formation (Jurassic), Axel Heiberg and Ellesmere Islands, district of Franklin. Bull. Can. Petrol. Geol. 21, 178-218.
Jones, D. L., Bailey, E. H., Imlay, R. W. 1969: Structural and stratigraphic significance of the Buchia zones in the Colyear Springs-Paskenta Area, Californa. Prof. Pap. U.S. Geol. Surv. 647-A, 24 pp.

Klimova, I. G. 1969: The early Berriasian of Western Siberia. Geol. Geofs. 1969, 4, 128-132 (In Russian).

Mesezhnikov, M. S., Zakharov, V. A., Shulgina, N. I., Alekseev, S. N. 1977: Evidence for the Ryazanian horizon on the Oka River obtained in 1976. Int. colloq. Upper Jurassic and Jurassic-Cretaceous boundary. Abstracts. Novosibirsk, 103-104. (In Russian).

Mesezhnikov, M. S., Zakharov, V. A., Shulgina, N. I., Alekseev, S. N. 1979: Stratigraphy of the Ryazanian horizon on the Oka River. In Saks, V. N. (ed.) Upper Jurassic and Jurassic-Cretaceous boundary, Novosibirsk. "Nauka". 71-80 (In Russian).

Mikhailov, N. P. 1966: Boreal Jurassic ammonites (Dorsoplanitinae) and zonal subdivision of the Volgian Stage. "Nauka", Moscow, transact. 151, $116 \mathrm{pp}$.

Neale, J. W. 1962: Ammonoidea from the Lower D beds (Berriasian) of the Speeton Clay. Palaeontology 5, 272-296.

Nikitin, S. 1884: Allgemeine geologische Karte von Russland, Blatt 56, Jaroslawl. Mém. Com. Géol. 1 (2), 153 pp.

d'Orbigny, A. 1845: Molusques. In Murchison, R. I., Verneuil, E. de \& Keyserling, A. de: Géologie de la Russie d'Europe et des montagnes de l'Oural, II, Paleontologie.

Pavlov, A. P. 1914: Jurassic and Lower Cretaceous Cephalopoda of Northern Siberia. Mém. Akad. Imp. Sci. St. Petersb. Cl. Phys. Ser 8, Cl. Phys.-Math. 21 (4), 1-68 (In Russian).

Pchelina, T. M. 1967: Stratigraphy and some characteristics of the composition of the Mesozoic sediments in the southern and eastern regions of Vestspitsbergen. In Sokolov, D. N. (ed.) Materials on the stratigraphy of Spitsbergen. NIIGA, Leningrad, 238 pp. (In Russian).

Piasecki, S. 1980: Middle to Late Jurassic dinoflagellate stratigraphy from Milne Land and Jameson Land (East Greenland) correlated with ammonite stratigraphy. Unpublished thesis, Copenhagen University.

Rolle, F. in press: Hydrocarbon Source Rock Sampling in Peary Land 1980. Rapp. Grønlands.geol. Unders.

Saks, V. N. (ed.) 1972: The Jurassic-Cretaceous boundary and the Berriasian stage in the Boreal realm. Novosibirsk. "Nauka", 371 pp. Translated from Russian, Israel Program for Scientific Translations Jerusalem, 1975. Keler Publishing House Jerusalem Ltd.

Sarjeant, W. A. S. 1979: Middle and Upper Jurassic dinoflagellate cysts: The World excluding North America. AASP Contr. Ser. 5B, 133-157.

Sazonova, I. G. 1971: Berriasian and Lower Valanginian ammonites of the Russian Platform. In The Berriasian of the Russian Platform (stratigraphy, ammonite fauna and aucellids). Mater. Pal. Nat. Geol. Inst. (VSEGEI) 110, 1110, 148-157 (In Russian).

Shulgina, N. I. 1969: Volgian ammonites. In Saks, V. N. (ed.) Key section of the Upper Jurassic deposits of the Kheta River Basin. "Nauka", Leningrad, sect. L, 125-162 (In Russian).

\section{PLATE 5}

Figs. 1-3: Buchia okensis (Pavlov, 1907). Early Ryazanian. 1a-c: right valve, left valve and posterior view, MGUH 15293 from GGU 196333; 2 left valve, MGUH 15294 from GGU 196331; 3: right valve, MGUH 15295 from GGU 196332.

Figs. 4-5: Buchia volgensis (Lahusen, 1888). Early Ryazanian. 4a-d: right valve, posterior and anterior view, and left valve, MGUH 15296 from GGU 196332; 5a-b: left valve and anterior view of left valve, MGUH 15297 from GGU 196332.

Figs. 6a-b: Buchia sp. indet. cf. keyserlingi (Lahusen, 1888), left valve and anterior view of left valve, Early Valanginian, MGUH 15298 from GGU 196345. 

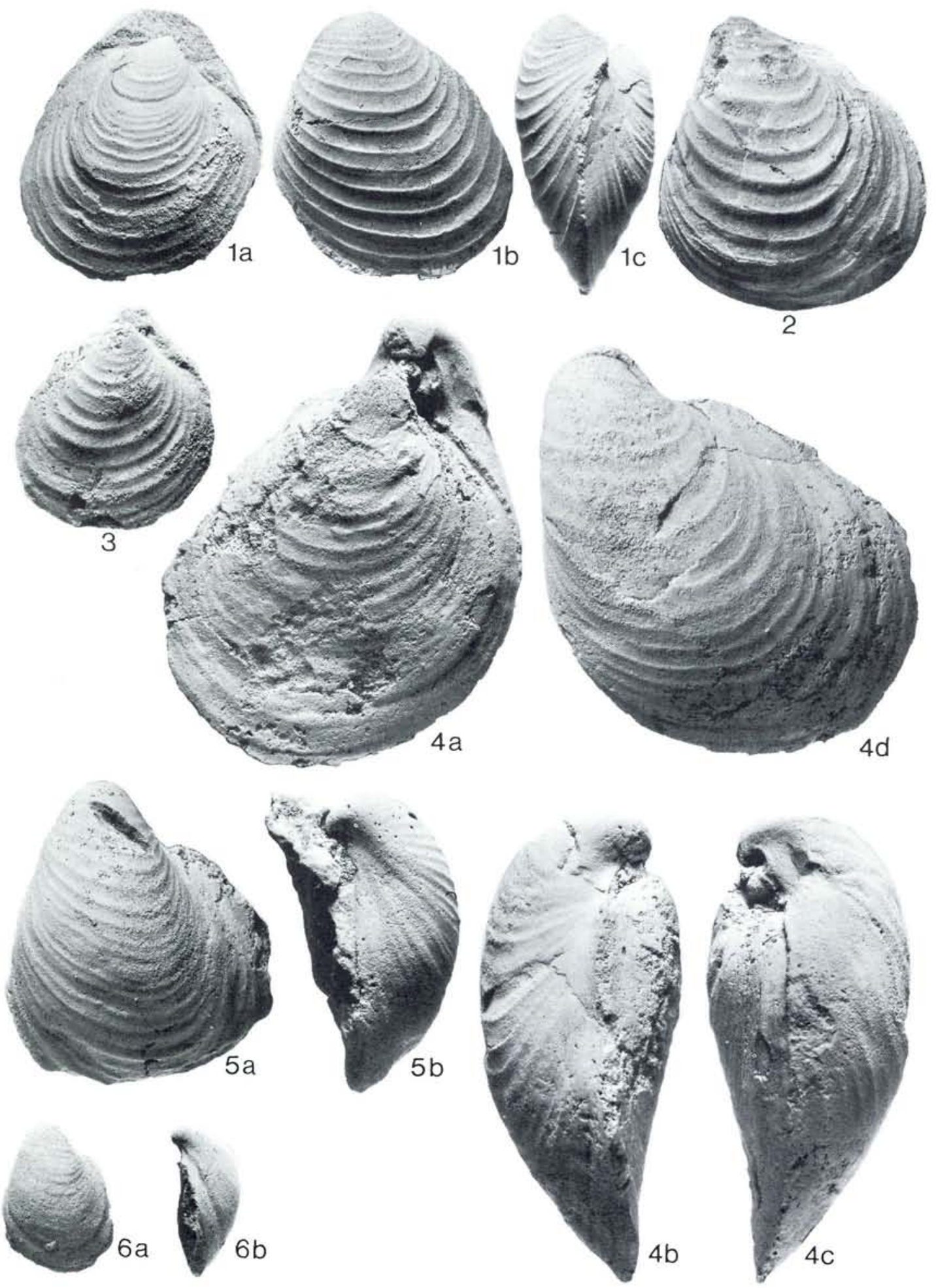
Sokolov, D. N. \& Bodylevsky, V. I. 1931: Jura- und Kreide Faunen von Spitzbergen. Skr. om Svalbard og Ishavet 35, $151 \mathrm{pp}$.

Spath, L. F. 1936: The Upper Jurassic invertebrate faunas of Cape Leslie, Milne Land. II. Upper Kimmeridgian and Portlandian. Meddr Grønland 99 (3), 180 pp.

Spath, L. F. 1947: Additional observations on the invertebrates (chiefly ammonites) of the Jurassic and Cretaceous of East Greenland. I. The Hectoroceras fauna of the SW Jameson Land. Meddr Gronland 132 (3), $70 \mathrm{pp}$.

Spath, L. F. 1952: Additional observations on the invertebrates (chicfly ammonites) of the Jurassic and Cretaceous of East Greenland. II. Some Infra-Valanginian ammonites from Lindemans Fjord, Wollaston Forland, with a note on the base of Cretaceous. Meddr Gronland 133(4), $40 \mathrm{pp}$.

Stover, L. E. \& Evitt, W. R. 1978: Analyses of Pre-Pleistocene organic-walled dinoflagellates. Stanford Univ. Publs Geol. Sci. 15, 300 pp.

Surlyk, F. 1973: The Jurassic-Cretaceous boundary in Jameson Land, East Greenland. In Casey, R. \& Rawson, P. F. (eds) The Boreal Lower Cretaceous. Geol. J. Spec. Iss. 5 , 81-100.
Surlyk, F. 1978: Submarine fan sedimentation along fault scarps on tilted fault blocks (Jurassic-Cretaceous boundary, East Greenland). Bull. Grønlands geol. Unders. 128, $108 \mathrm{pp}$.

Sykes, R. M. \& Callomon, J. H. 1979: The Amoeboceras zonation of the Boreal Upper Oxfordian. Palaeontology 22(4), 839-903.

Tan, J. T. \& Hills, L. V. 1978: Oxfordian-Kimmeridgian dinoflagellate assemblage. Ringnes Formation, Arctic Canada. Geol. Surv. Can. Pap. 78-1c: 63-73.

Voronets, N. S. 1962: The stratigraphy and cephalopod molluscs of the Jurassic and Lower Cretaceous deposits of the Lena-Anabar area. Mater. Inst. Geol. Arkt. 110, 237 pp. (In Russian).

Zakharov, V. A. 1981: Buchiidae (Bivalvia) and biostratigraphy of the boreal Upper Jurassic and Neocomian. Trans. Inst. Geol. Geophys. Academy Sci. USSR Moscow (In Russian).

Zakharov, V. A. \& Mesezhnikov, M. S. 1974: The Volgian Stage of the Subarctic Ural. Novosibirsk. "Nauka", 216 pp. (In Russian). 

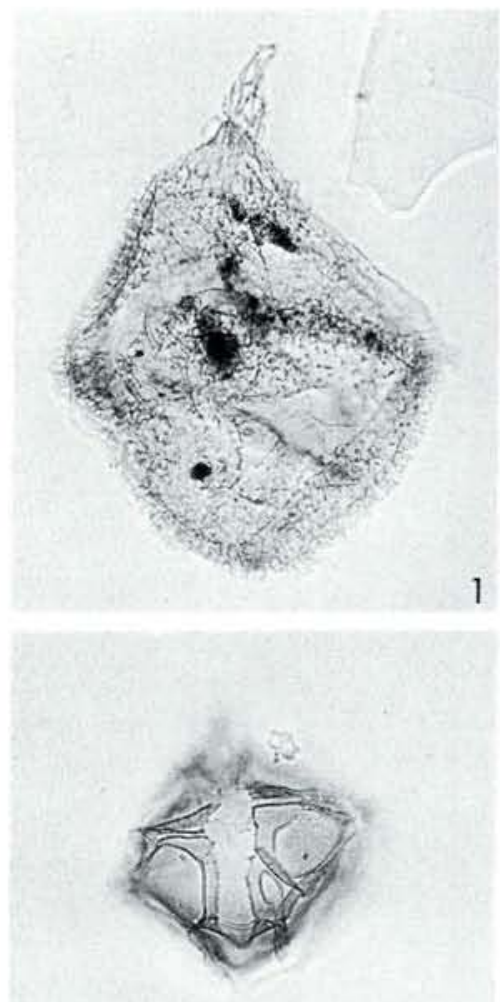

3

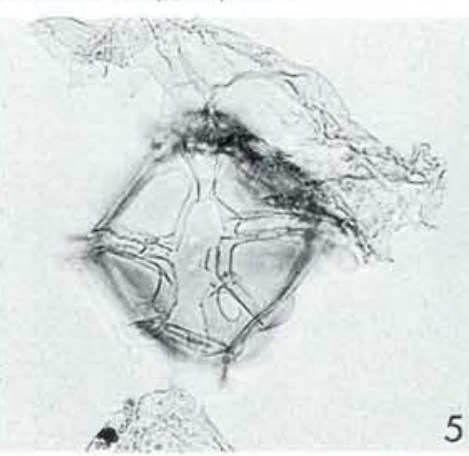

5

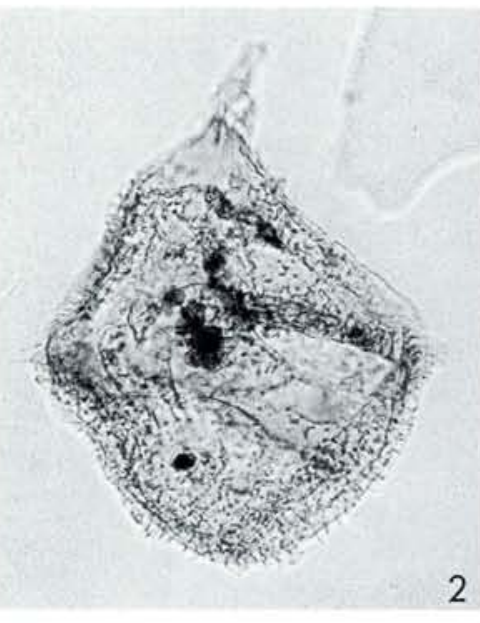

2

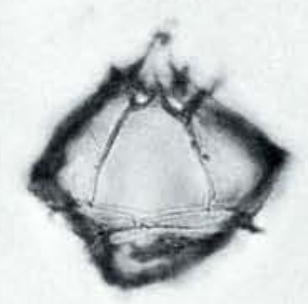

4
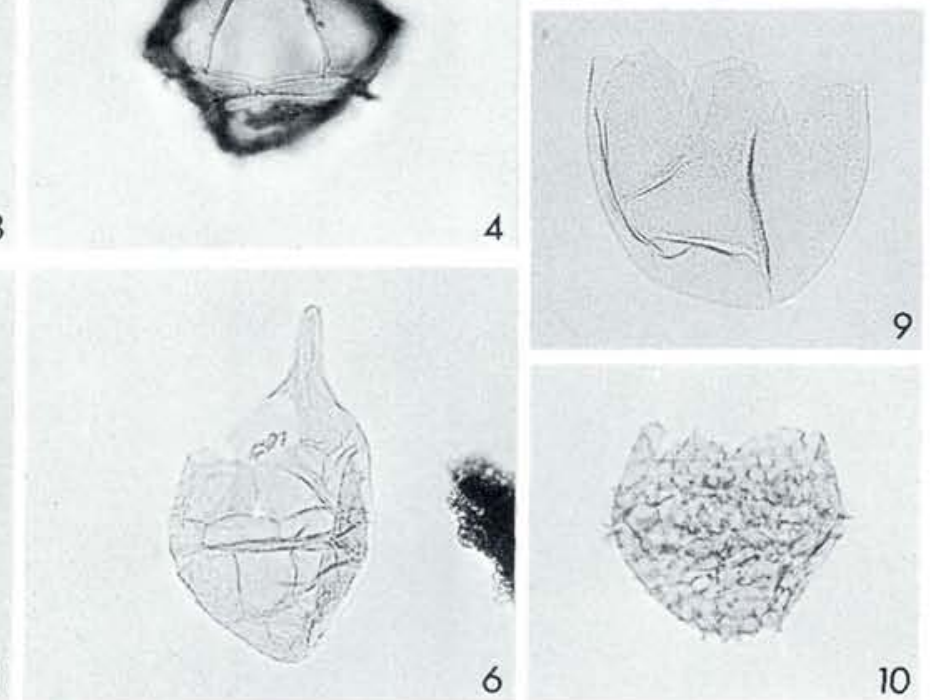

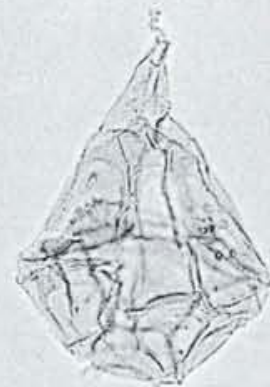

7

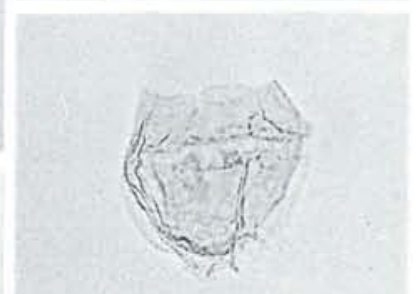

8

6

10

\section{PLATE 6}

Figs. 1-2: Gonyaulacysta scarburghensis, MGUH 15299 from GGU 196336; high and low focus. Figs. 3-4: Leptodinium aff. hyalodermopsis, MGUH 15300 from GGU 196317; ventral and dorsal view. Fig. 5: Leptodinium aff. hyalodermopsis, MGU 15301 from GGU 196317; ventral, view, paraplate 1"' clearly differentiated. Fig. 6: Paragonyaulacysta borealis, MGUH 15302 from GGU 196196. Fig. 7: Gonyaulacysta jurassica subsp. longicornis, MGUH 15303 from GGU 196338. Fig. 8: Ambonosphaera sp., MGUH 15304 from GGU 196338. Fig. 9: Sentusidinium myriatrichum, MGUH 15305 from GGU 196350. Fig. 10: Lanterna saturnalis, MGUH 15306 from GGU 196296. All figs approx. $500 \mathrm{x}$. 


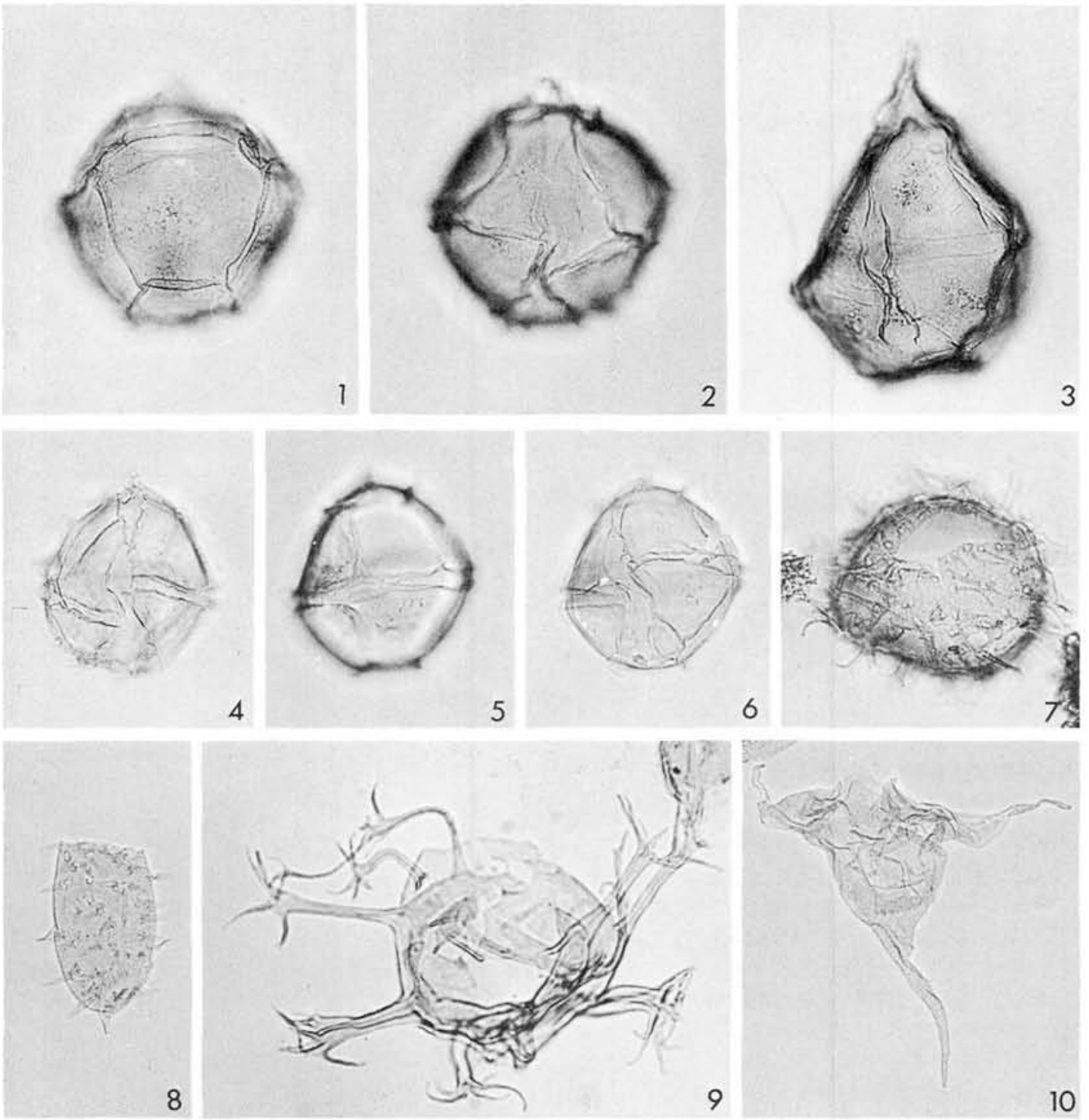

PLATE 7

Figs. 1-2: Gonyaulacysta sp. 1, MGUH 15307 from GGU 196192; spherical main body in dorsal and ventral view; the parasulcus is strongly sigmoidal. Fig. 3: Gonyaulacysta sp. 1, MGUH 15308 from GGU 196192; polygonal main body; well developed epicoel. Fig. 4: Gonyaulacysta helicoidea, MGUH 15309 from GGU 196345. Figs. 5-6: Gonyaulacysta helicoidea, MGUH 15310 from GGU 196345; dorsal and ventral view. Fig. 7: Cleistosphaeridium sp., MGUH 15311 from GGU 196350. Fig. 8: Tanyosphaeridium isocalamus, MGUH 15312 from GGU 196334. Fig. 9: Oligosphaeridium complex, MGUH 15313 from GGU 196326. Fig. 10: Muderongia tetrachanta, MGUH 15314 from GGU 196326. All figs approx. $500 \mathrm{x}$. 